\title{
Urban Vulnerabilities in the Kathmandu Valley, Nepal: Visualizations of Human/Hazard Interactions
}

\author{
Keshav Bhattarai ${ }^{1}$, Dennis Conway ${ }^{2}$ \\ ${ }^{1}$ Department of Geography, University of Central Missouri, Warrensburg, USA \\ ${ }^{2}$ Department of Geography, Indiana University, Bloomington, USA \\ E-mail: bhattarai@ucmo.edu,conway@indiana.edu
}

\begin{abstract}
Excessive unplanned urban growth leads to many vulnerabilities and impacts on urban environments to varying degrees. However, the majority of the extant literature focuses on the problems related to location and socioeconomic conditions, rather than vulnerability processes and related environmental degradation. This paper analyzes the scope of urban vulnerabilities for five rapidly urbanizing and highly-congested cities in the Kathmandu Valley, Nepal. First, the historic context of the Valley's uncontrolled urbanization sets the scene. Second, the optic is narrowed to focus upon the geographical features of the resultant urbanized Valley landscape that includes spatial arrangements and of houses, population densities, road networks, vehicular densities, garbage problems, and available open spaces. Additionally, seismic vulnerabilities in the urban areas are also considering in this examination. Third, three-dimensional visualizations of selected urban locations are presented to differentiate between vulnerable and relatively safe locations. The intent of this research is to contribute to the methodological understanding of human/hazards interactions in rapidly urbanizing cities of the Third World, which share similar socioeconomic conditions and environmental contexts.
\end{abstract}

Keywords: Urban Vulnerability, Planning, Kathmandu Valley, Two Dimensional (2D) Maps, Three Dimensional (3D) Visualization

\section{Introduction}

Urban vulnerability analysis using spatio-temporal information is increasingly used by urban planners and policy makers to anticipate and prevent catastrophic human disasters. Throughout the world, urban centers are becoming environmentally complex; home to over half of the world's population, these centers provide employment and commerce opportunities as well as administrative services to residents. Even in smaller urban centers many complex infrastructures have been developed to provide essential amenities to their overcrowded urban populations. At the same time, organic (haphazard/unplanned) developments often lead to increased vulnerability, and in many cases a variety of urban vulnerabilities, that taken together, make public solutions difficult if not impossible to anticipate, ameliorate or address adequately. The identification of such "mixes of vulnerabilities" requires sophisticated spatial analysis to understand the interactions among biophysical and economic factors that bring about such heightened vulnerabilities.
Over the past two and half decades, the integrated use of geographic information systems (GIS), global positioning systems (GPS), and remote sensing has become instrumental in addressing urban vulnerabilities at the local, national, and international levels [1-4]. Using these tools to analyze the landscape, researchers have identified numerous urban vulnerabilities resulting from a lack of emergency vehicular accesses and open spaces, uncontrolled solid waste management, and related unhygienic conditions, to name a few. To date, methodological approaches to identify and monitor urban vulnerabilities are limited and inconsistent due to an absence of uniform concepts, rules, and principles among academics and practitioners. To help remedy this situation, this paper analyzes spatial arrangements and housing types, population densities, road networks, vehicular densities, garbage problems, available open spaces and possible seismic vulnerabilities using $3 \mathrm{D}$ visualization techniques for the Kathmandu Valley of Nepal. One goal is to identify gaps within the extant of urban literature. A secondary goal is to explain how urban density-intensification not only results in declining rates of economic returns 
per land area unit $[3,5]$, but also how such density-intensification hinders accessibility in cases of natural disasters such as Haiti's 2010 earthquakes, negatively impacts hygienic conditions, and threatens the public's health.

Urban vulnerabilities are the result of the complex interaction of biophysical and economic factors. The identification of such intertwined complex interactions requires three-dimensional (3D) $\mathrm{x}, \mathrm{y}$, and $\mathrm{z}$ information, due to the fact that two-dimensional (2D), $x$ and $y$, information produces incomplete and therefore, inadequate scenarios for analyzing future urban landscape trajectories. We take a 3D visualization approach and use combinations of different datasets, such as GIS layers of multi-layer building morphologies, satellite images, and high resolution digital elevation data models (DEM) to assess vulnerabilities. More specifically, these visualizations evaluate: a) man-made hazards in congested urban areas; b) access to roads and bridges by emergency vehicles; and c) highlight the importance of such infrastructure patterns in politics, culture, economy and finance. Similar purposeful, three-dimensional visualizations will make it easier to implement settlement planning in locations such as the Kathmandu Valley, considering the challenges routinely faced by national and regional planners in Third World urban centers. In addition to regularly addressing the problems of slums, squatters, inadequate lowincome housing and overburdened infrastructure systems, urban planners of the Third World may also have to work within a corrupt political system and with an equally inefficient governmental bureaucracy [5]. Planners and policy makers should find 3D data valuable not only to present long-term urban trajectories, but also to overcome undue pressures from politicians who routinely get their votes from the slums and squatter dwellers and who generally look for immediate problem-solving approaches in an organic fashion [5]. Instead, 3D presentations can illuminate planned outlays to promote sustainable solutions based on scientific, methodological analysis.

Using spatial information within an urban theoretical framework, we analyze urban vulnerabilities of the Kathmandu Valley (Figure 1). To address urban vulnerability issues, this paper is structured as follows: 1) research questions; 2) literature review; 3) brief description of the study area; 4) data and methodology; 5) causes of urban vulnerabilities; 6) remediation procedures to alleviate congestion problems, and 7) conclusion.

\section{Research Questions}

1) What determines urban vulnerabilities, and what factors make some urban areas more vulnerable than others? 2) Is it possible to identify repeated patterns of urban vulnerabilities and if so, how might such vulnerabilities be ameliorated?

\section{Review of Literature}

Research has identified a mix of urban vulnerabilities [6-9]. As a spatial science, geography concerns itself with the behavior and distribution of: 1) urban objects, such as residential and commercial buildings, pedestrians, and vehicles; 2) urban features, such as land parcels, shops, roads, sidewalks; and 3) natural features, such as green/ open spaces, rivers, and the seismic vulnerability of places. Spatial science considers these dynamic factors as "urban ensembles," which vary at different locations and scales [10]. Some researchers have used simulation methods to view the roles of these ensembles in urban amenities Torrens [11] while Blaikie et al. [12] have taken a theoretical approach and defined vulnerability as being prone to, or susceptible to, damage or injury due to biophysical factors. Rasheed and Week [13] relate urban vulnerabilities to natural hazards such as earthquakes, and to human behavioral adaptations; and argue that urban vulnerabilities become intertwined with socioeconomic systems. The World Vulnerability Report (2003) presented 50 different indicators of urban vulnerabilities by analyzing "urban ensembles" at various scales.

Urban ensembles such as buildings, streets, bridges, public and industrial areas, roofs, facades, open and green spaces, are obviously highly interrelated, but they can be visualized using design plans, drawings, and video data records [14]. Various layers such as houses, critical facilities, industrial sectors, and others can be overlaid together for visualization and subsequent spatial analysis. Researchers often apply spatial, multi-criteria approaches using spatial objects to examine the quality of life, urban conditions and aesthetic structures, because these "urban ensembles" represent dynamic phenomena involving people not only as users but also as victims, contributors, and modifiers [15-21]. Remote sensing and GIS technologies have proved to be especially-helpful tools to identify vulnerable and/or non-vulnerable ensembles across urban landscapes.

Alexander [6] used GIS to locate areas within seismic zones and analyzed the degrees of urban vulnerability they posed. Webster [22] used GIS at three levels of analysis: describing, predicting, and prescribing the growth and associated problems within an urban area. Cutter [23] used GIS to develop weighted social and biophysical indicators associated with urban vulnerability. $\mathrm{Wu}$ and Webster [3] hypothesized an artificial city and created a multi-dimensional matrix model as $P$ grids each consisting of $n \times n$ cells to demonstrate the power of GIS as an integrative exploratory tool within the geographical, complex systems and economic theories. They argued that a city constantly shifts spatially achieving fraction of the cells, starting with pre-existing residential and industrial uses, initializing the majority of cells as vacant and then presented several possible scenarios of urban morphologies. 

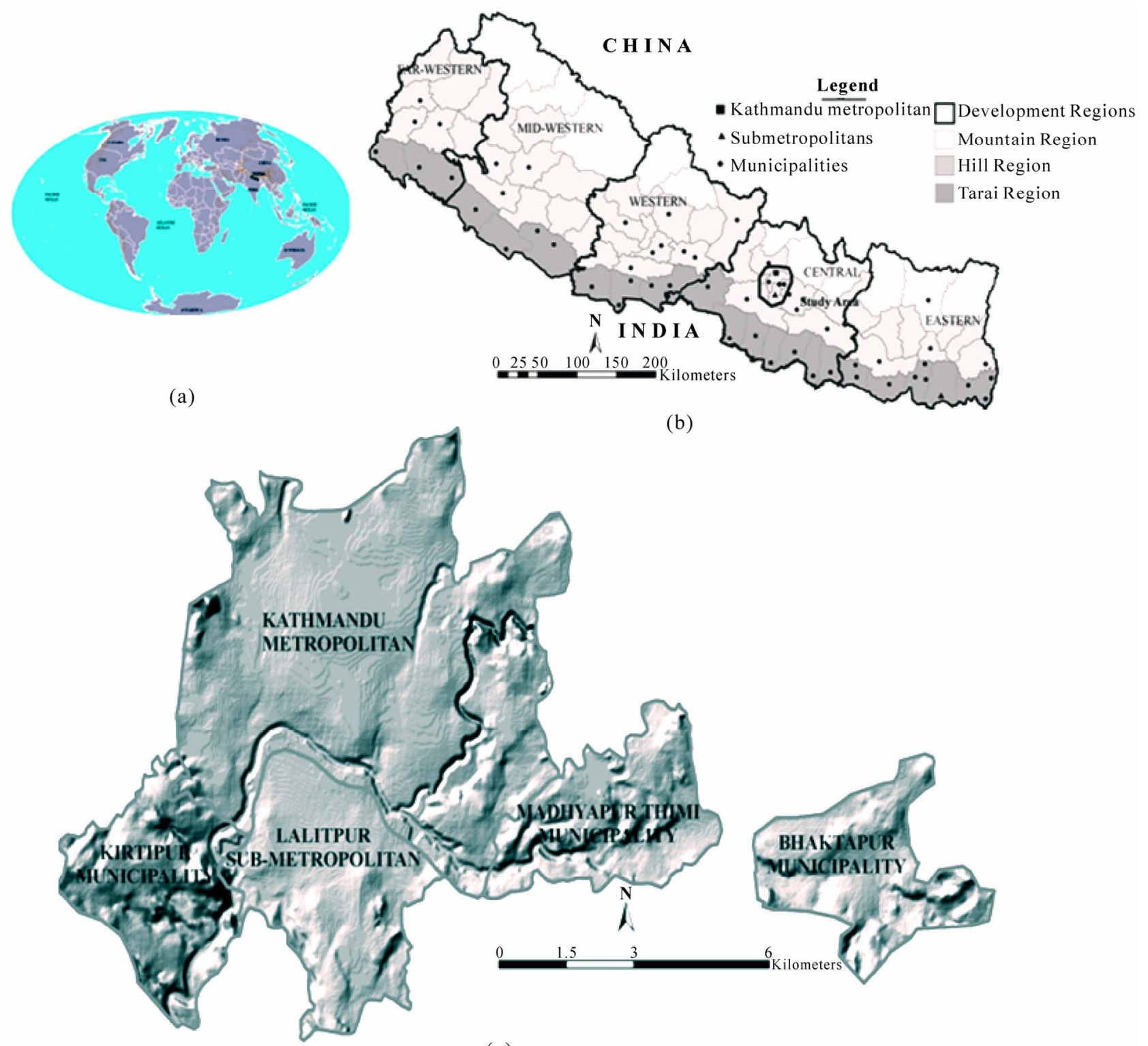

(c)

Figure 1. Map of the (a) world, (b) Nepal, and (c) Kathmandu Valley showing five urban centers.

Further, they analyzed the agglomeration effect in a city through a moving kernel, which returns a parameter that is a function of the number of built-up activities in the immediate neighborhood. They argue households in a community are assumed to place a measurable value on such development, which may add to both urban amenities and vulnerabilities due to their causal linkages. Madhavan et al. [24] used remote sensing to explain how land use and land cover changes are associated with urban vulnerabilities in the Metropolitan area of Bangkok, Thailand. Rashed and Weeks [2] explained how a society might be subjected to various hazards because of its own actions, such as construction of unaesthetic and congested structures such as substandard buildings and nar- row roads.

Bhaskaran et al. [25] analyzed vulnerability due to hail damage in urban areas of Sydney, Australia, using remote sensing techniques. They determined the need for a higher concentration of post-disaster emergency operations in areas with less resistant roofing materials. Bottari et al. [26] identified seismic urban vulnerabilities citing examples from Sicily using GIS techniques. Li et al. (2006) used quantitative models using GIS and remote sensing and analyzed urban vulnerabilities associated with environment conditions in the upper reaches of the Minjiang River, China. Zamoranoa et al. [27] used GIS techniques to develop indices to determine appropriate locations for waste disposal. Kamozawa et al. [28] studied vulner- 
abilities associated with bed rock movements during earthquakes using 3D features.

Researchers have found the 3D visualization technique useful in examining the effects of adjacency (what is next to what), containment (what is enclosed by what), proximity (how close one geographic object is to another), accessibility (how an object can be reached from a certain road), and visibility (how far certain objects are visible from certain locations) [29]. However, as in simple two-dimensional features, it is essential in $3 \mathrm{D}$ features to either associate the distance and direction with the object as an attribute to the housing unit, or to compute the distance and direction between the roads and houses along with the height or depth of individual objects. This requires the storage of extra attribute information, i.e. latitude, longitude, height or depth, (and/or time). In earlier times, 3D visualizations were possible only in computer-aided design (CAD) [30,31] and cadastral mapping [32]. Today, ArcGIS 9.4 beta version incorporates 3D functions in its Network Analyst [33], making it accessible and functionally more useful to planners and researchers alike in the accessibility analyses [34].

Urban vulnerability analysts have found 3D models very efficient for correlating societal and biophysical factors while working in unfamiliar locations [2,35]. Others have used $3 \mathrm{D}$ visualization to display remotely sensed images and to analyze ozone and nitrous oxide concentration and dispersal patterns [36]. The use of $3 \mathrm{D}$ is also increasing in transportation planning with the use of a lane-oriented, 3D road-network model [37], though very little research has been done in this area to date. Since 2D road network data does not have sufficient accuracy for lane-oriented micro-scale, the recent development of sensor technology has been recommended for the development of road layers with higher positional accuracy that use differential GPS, often termed as DGPS receivers. Moreover, the rapid development of digital photogrammetric cameras to capture lane oriented data has improved the quality of 3D data [38]. These 3D road lane data are useful to predict both upward and downward (flyovers, tunnels, over/underpass) movements of vehicles [39], which is not possible with 2D data. The 3D model maintains the integrity of the network data and provides better compatibility with the general hierarchical view of roads. Its dynamic segmentation outperforms traditional 2D dynamic segmentation in accuracy and flexibility. Companies like Vexcel Corporation based in Boulder, Colorado, are producing 3D models of the world from custom satellite data with high accuracy. However, these images are currently cost prohibitive.

The above account highlights the methodological advancements using spatially referenced data, beginning with a simple $2 \mathrm{D}$ version and progressing to a much more complex 3D methodological framework. Though many studies have analyzed the Kathmandu Valley's urbanization patterns, to date nobody has used 3D visualization to analyze possible urban vulnerabilities in a Valley wherein the urban areas have expanded $450 \%$ between 1950 and 2000 [40]. Past research on Kathmandu urbanization includes cartographic visualization and historical descriptions [41] and analyses of urban sprawl using remote sensing and GIS techniques [42-46]. We intend to conduct research and present evidence that reveals the usefulness and value of 3D visualization techniques by examining adjacency, proximity, accessibility, and environmental conditions within the uncontrolled and unevenly patterned conurbation of Nepal's Kathmandu Valley.

\section{Study Area}

The Kathmandu Valley is facing potentially insurmountable challenges due to overpopulation by immigration and natural growth. Traffic jams, a polluted environment, and rapid changes in the socio-cultural diversity are common features of this valley. Unplanned urban development fostered by weak institutional arrangements has encouraged rapid and uncontrolled urban sprawls which have contributed to dramatic changes in the urbanized landscape. Road blockages and the incessant shutting down of educational institutions, government offices, factories and shops due to political agitations have become common occurrences. Garbage disposal has become a political issue as well as a health hazard. As vulnerable as this city is to political unrest and garbage pollutants, the possibility of a high intensity earthquake (Figures 2(a) and (b)) is perhaps the greatest threat to the city and its inhabitants [47].

Geologically, the Kathmandu Valley is as vulnerable as Haiti, which experienced a devastating 7.0 earthquake on January 13, 2010 that resulted in the loss of over 200,000 lives, and left half a million people (a third of the nation) homeless [48]. Seismic geologists attribute the huge loss of life and property to the location of the quake's epicenter, near the capital in Port-au-Prince, and the construction of substandard buildings that commonly are not build according to seismic codes. Even the Presidential Palace of Haiti was damaged. Seismic geologists in Asia fear that the Kathmandu Valley might face a similar situation due to four reasons: 1) the Kathmandu Valley lies between the two young and active Eurasian and Indian Plates, similar to Haiti's location between Caribbean and North American plates; 2) many fault lines crisscrossing the Valley; 3) the soft floor of a prehistoric lake; and 4) the occurrence of many violent earthquakes in the past. 


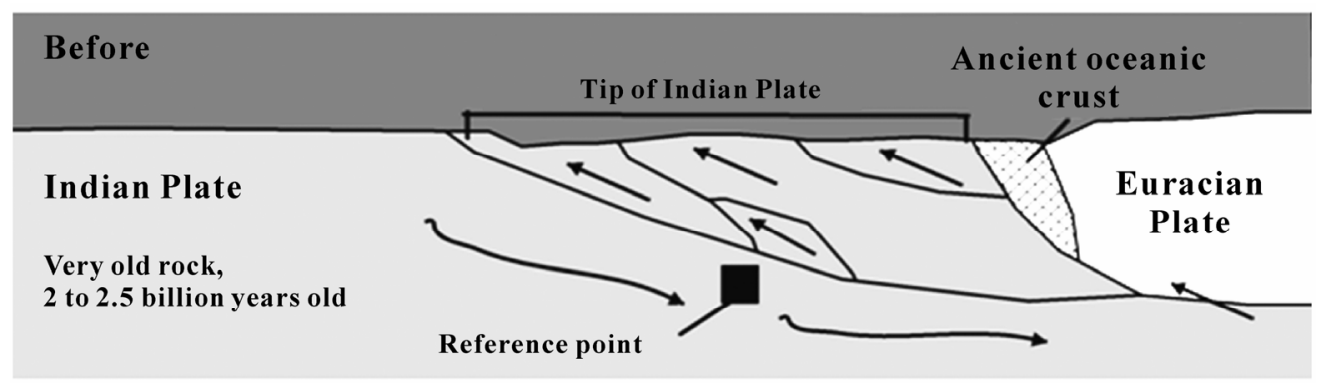

(a)

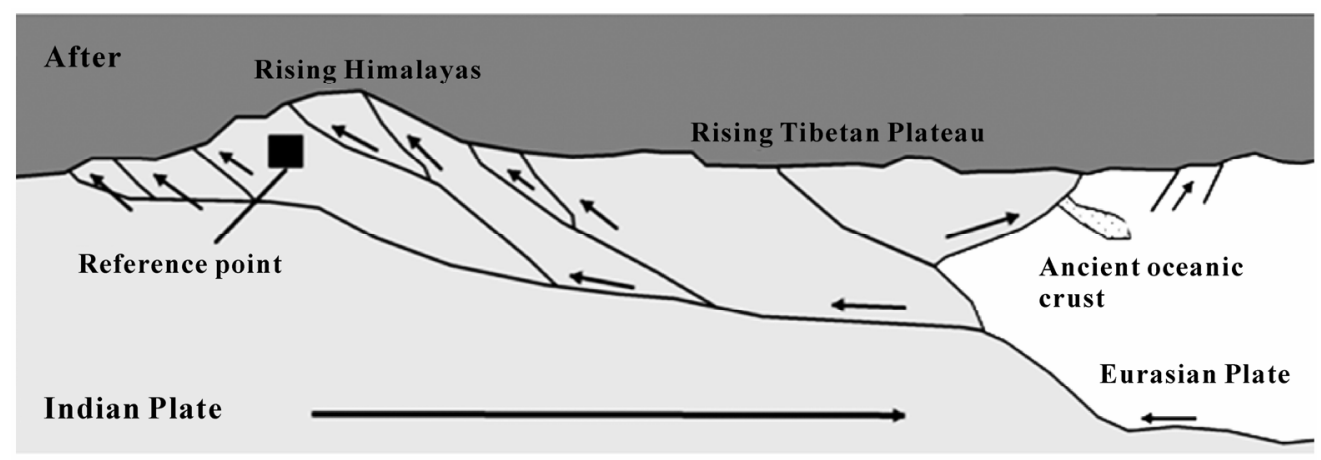

(b)

Source: Digitized from the base map of: http://pubs.usgs.gov/gip/dynamic/understanding.htm and Figures 2(a) and (b). The meeting of the Indian and Tibetan Plates is influencing the Himalayan arc. The Himalayan mountain range dramatically demonstrates one of the most visible and spectacular consequences of plate tectonics. When two continents meet neither is subducted, because the continental rocks are relatively light and, like two colliding icebergs, resist downward motion. Instead, the crust tends to buckle and is pushed upward or sideways.

Figure 2. (a) and (b) Location of Nepal with reference to Indian and Eurasian plates.

The great 8.4 earthquake of 1934 hit Nepal on January 16, 1934, and killed 16,775 people, damaged 318,000 houses, and left thousands homeless. A recent report by the Japan International Cooperation Agency (JICA) estimates that if an earthquake of the same intensity were to hit the Kathmandu Valley, 50 percent of the buildings would be damaged while $10-15 \%$ percent of Kathmandu's 750,000 populations would likely be killed within the building rubbles because many of the areas are inaccessible by emergency vehicles.

Another recent study on the movement of tectonic plates and history of Himalayan earthquakes has predicted that the next great earthquake may hit the "central gap" of the Himalayas of Nepal at any time $[47,49,50]$.

If an earthquake measuring greater than $5 \mathrm{M}_{\mathrm{w}}$ occurs in the Kathmandu Valley, many large structures, such as temples and monasteries constructed of heavy rocks, bricks, mud-mortar, masonry, and timber, as well as individual houses built with adobe, stone, mud-mortar, brick-cement, and masonry (Figure 3), having low tensile strengths, are likely to be destroyed. Dixit [47] argues that if an earthquake of similar magnitude to that of 1934 occurs, over 60 percent of the houses and over 50 percent of bridges will collapse, and the city would likely lose telephonic connections. An earthquake of similar $\left(6 \mathrm{M}_{\mathrm{w}}\right)$ magnitude in Eastern Turkey on March 8, 2010 leveled off all the mud-mortar buildings of a village trapping people under the rubble of collapsed buildings [51]. However, there were minimal damages in cement concrete buildings. Most of the old mud-mortar and stone buildings of the Kathmandu Valley are similar to those of Turkey's rural areas. Dixit [47] argues that aid from foreign countries may get stuck at the airport, which is likely to be cut off or suffer from transportation bottlenecks (like the airport in Haiti). The resultant difficulties in rescuing the injured and distributing aid to the impacted population will inevitably result in more fatalities [47].

Over the years, the trends of rapid urbanization and haphazard (re)development activities in the core historical areas and peripheral agricultural lands, have exposed an increasing percentage of the population to seismic hazards, and have decreased the capacity of emergency services to cope with challenges associated with disasters. Many private schools, colleges, other educational institutions and private nursing homes, which should serve as "evacuation shelters" and "treatment centers" in the event of an earthquake striking the Valley, are currently operating in ordinary, residential substandard buildings. The 


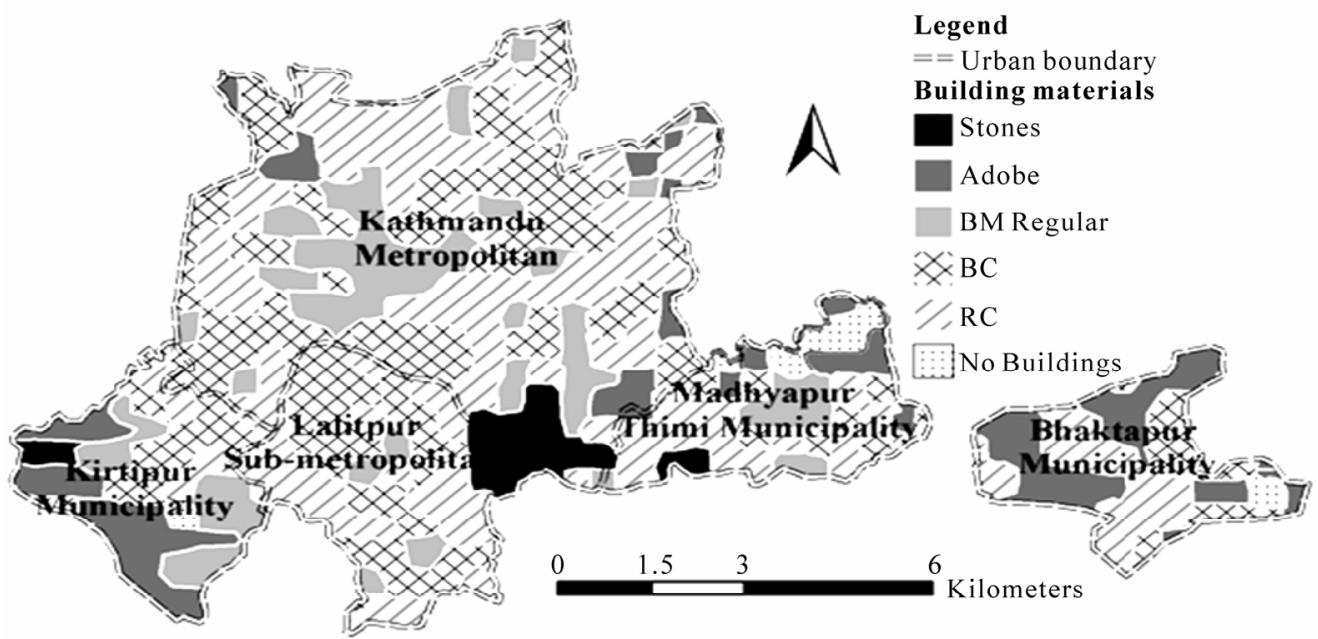

(a)

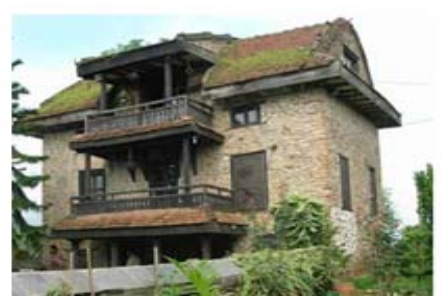

(b)

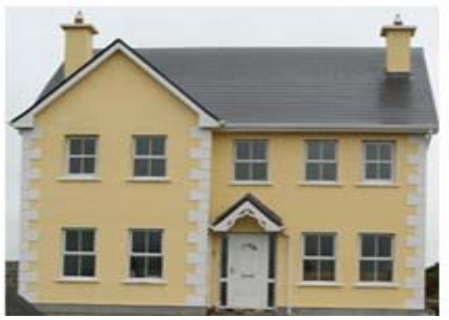

(e)

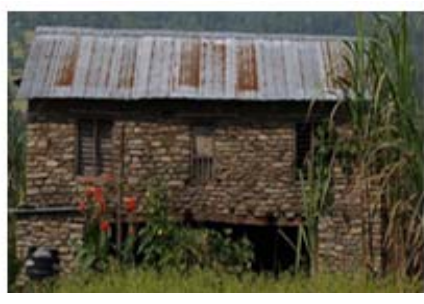

(c)

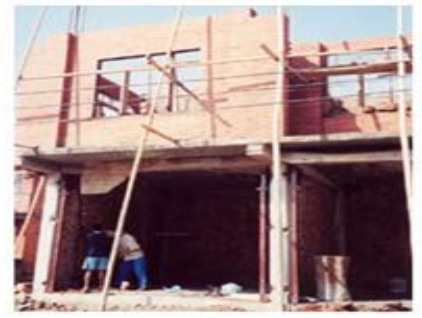

(f)

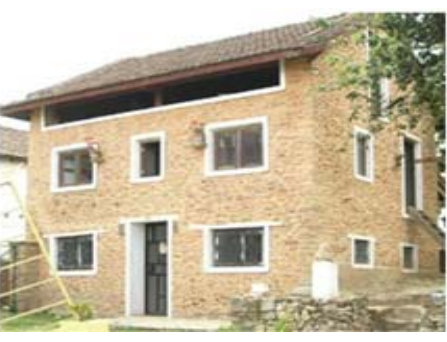

(d)

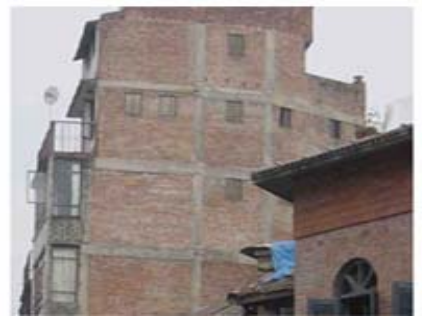

(g)

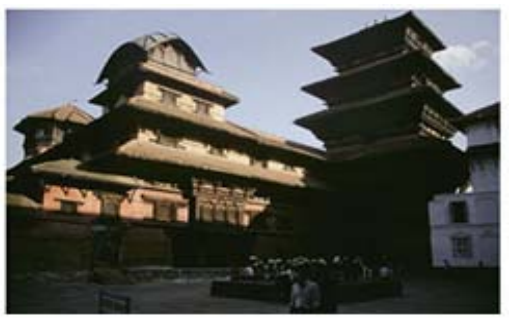

(h)

Figure 3. (a) Building types in five urban areas; (b) Adobe built; (c) Stone built; (d) Adobe well-built; (e) BM well-built; (f) Brick Cement; (g) RCC Pillar; (h) Temples and residential buildings.

replacement of old three- and four-story residential houses with eight- to ten-story commercial office complexes in the urban centers has transformed narrow pedestrian lanes, street squares and courtyards into parking lots, garbage dumping sites, and "death traps". The riverfronts, prone to flooding in the event of an earthquake, are filled with slum and squatter settlements [50,52].

Geologists argue that conditions have ripened for a mega earthquake to strike Nepal $[47,53]$ suspecting major devastation like that of Haiti in 2010. A simulation conducted 
by the National Society of Earthquake Technology Nepal, suggests that stone-built and adobe buildings sustain heavy damages even in the normal peak ground acceleration (PGA) of earthquakes. Studies of the 1934 earthquake damage reveals that houses with: few stories, few widows, large open spaces between them, wedge-walls (joists and walls interlocked with each other) with two bricks of adjacent layers put perpendicular to each other, light upper stories, made of good quality lime mortar with thick walls and deep foundations, more wooden structures than brick pillars, are more durable than houses without these attributes [54]. Since the houses of the Valley's city core areas are built in a more compact environment (Figures 4(a) and (b)), they are likely to sustain more casualties in the event of a high intensity earthquake.

Joshi $[54,55]$ studied the damages that occurred in brick and stone masonry structures during the 1934 earthquakes and discovered that structures built by intermediate tech-

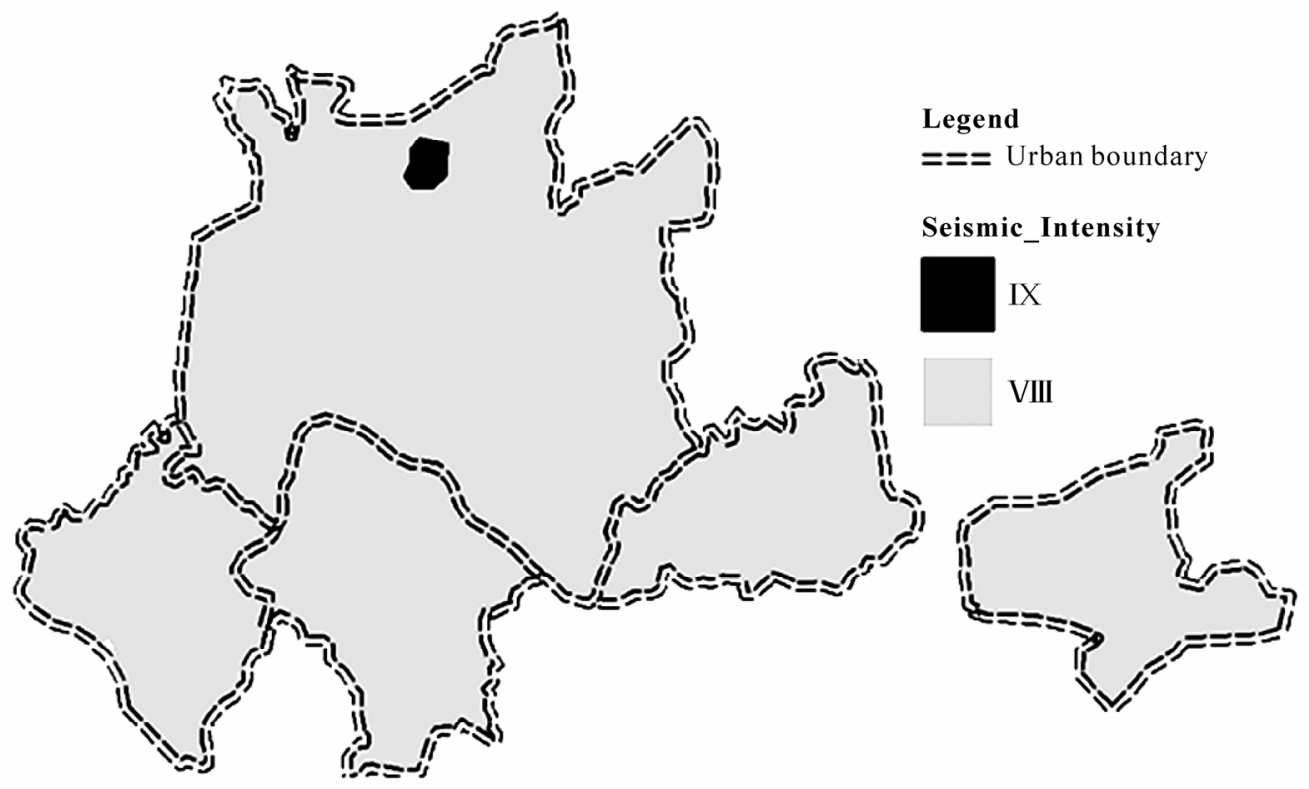

(a)

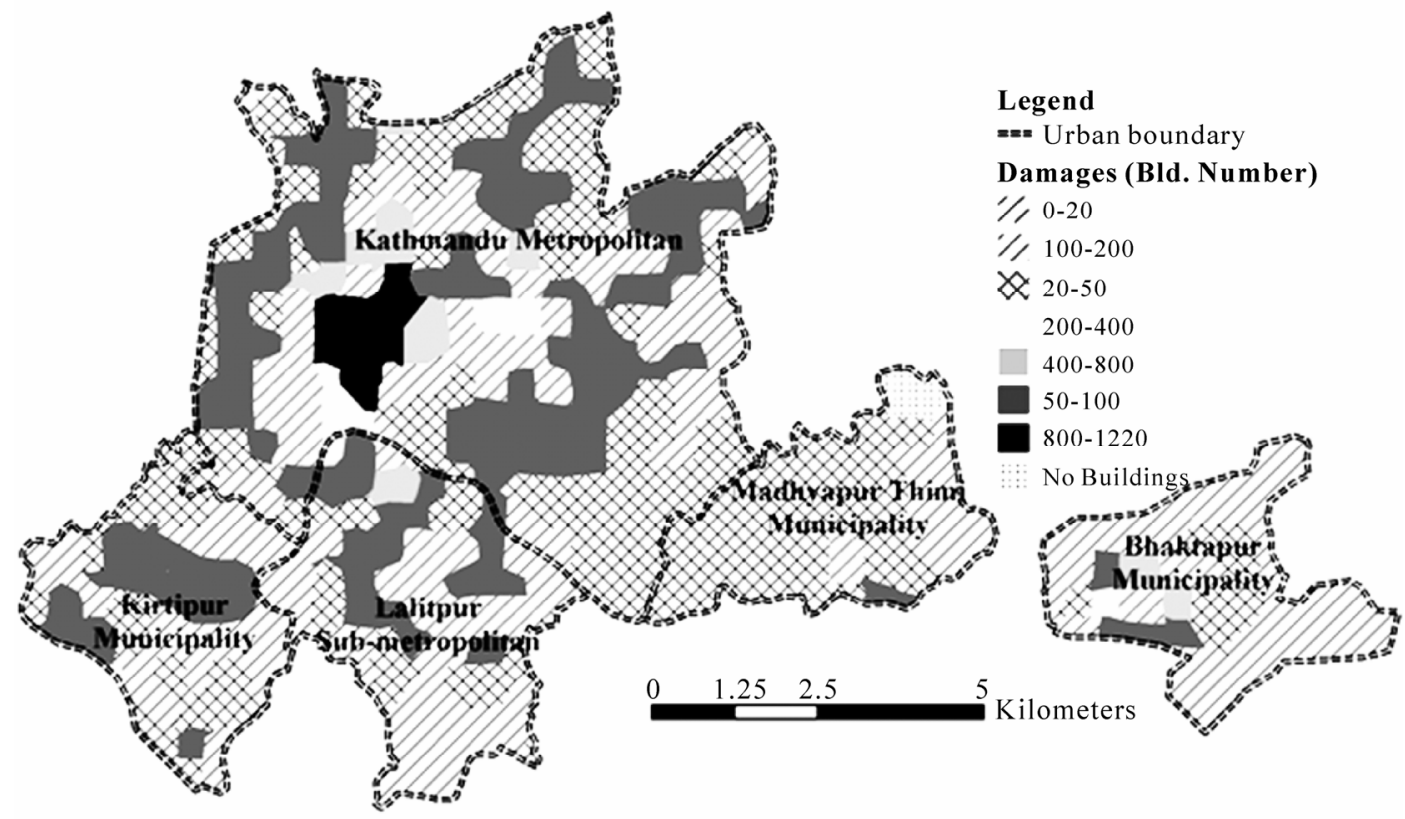

(b)

Figure 4. (a) and (b) Earthquake intensity and building damages. 
nology suffer the most damage because of their low tensile and shear strength when the ground shakes at a higher scale. Because of the low tensile strength of materials used to build temples and monasteries, if an earthquake occurs, people living close to these structures would be more vulnerable than individuals were during the 1934 earthquake due to overcrowding and increased population densities. Today, a growing number of people are living close to low tensile structures, which were previously only located in tranquil and contemplative environments away from settlements. Successive waves of economic restructuring and population growth are reflected in the on-going development patterns of the Kathmandu Valley (Figure 5) resulting in rising land prices and sub-standard housing structures in the Valley [56] and urban sprawl into the hinterlands (Figure 6).
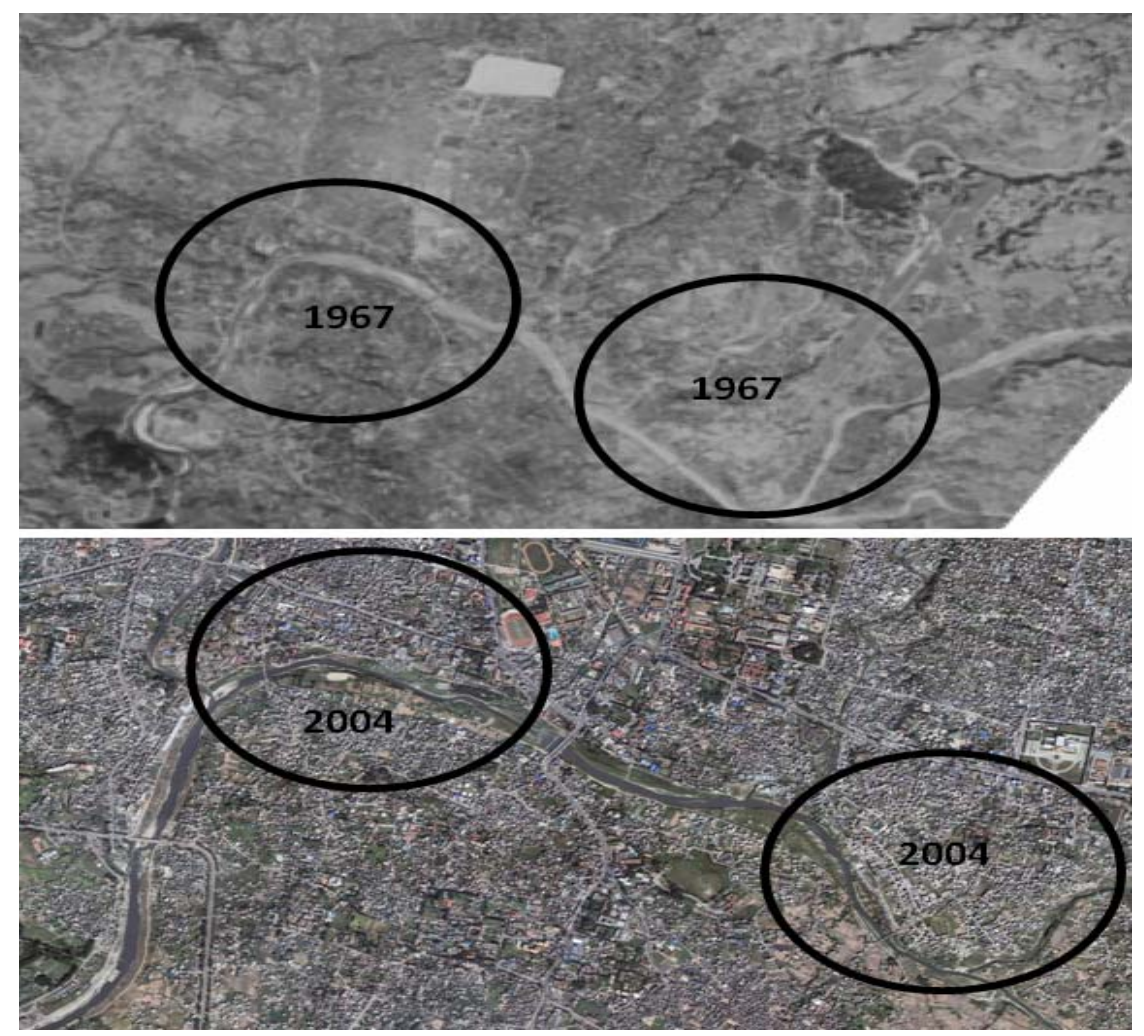

(a)
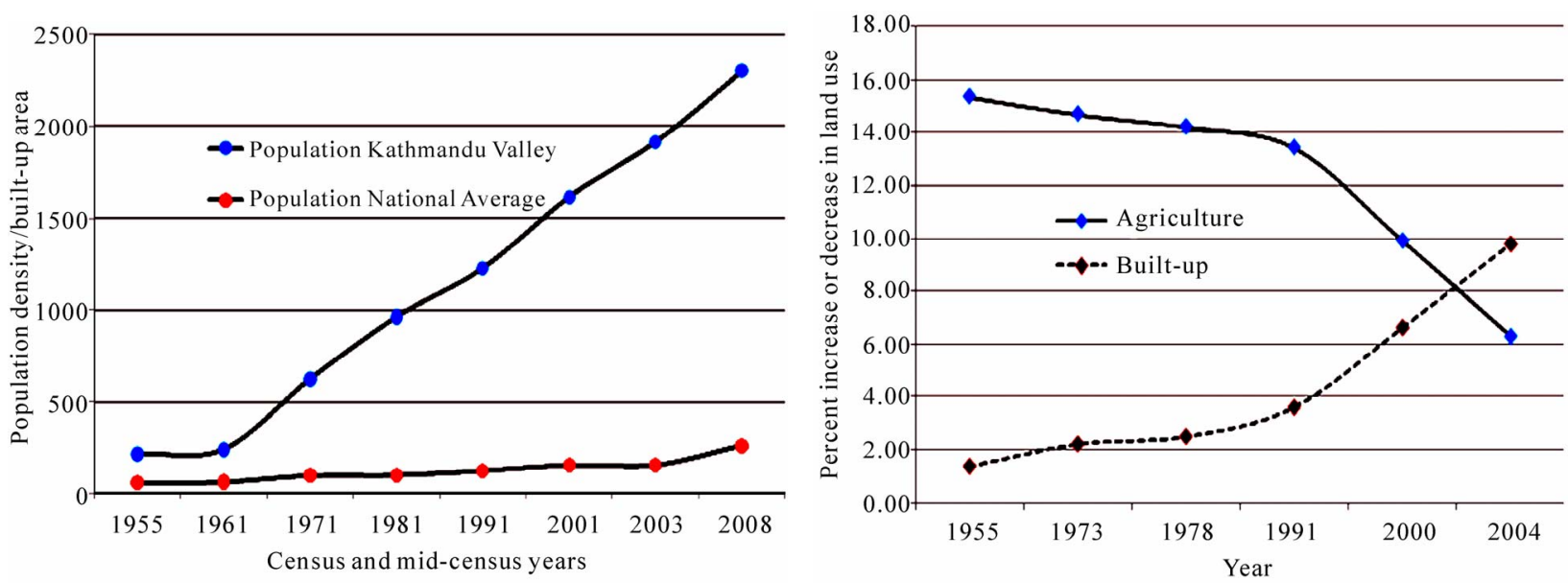

(b)

Figure 5. Kathmandu Valley: Once a fertile rice field (Aerial photo, (a)) has been turned into a concrete jungle (IKONOS image (a) as the Valley's population density is increasing at a much faster rate than the national average; (b) increasing the built-up area at the cost of agricultural land (b). 


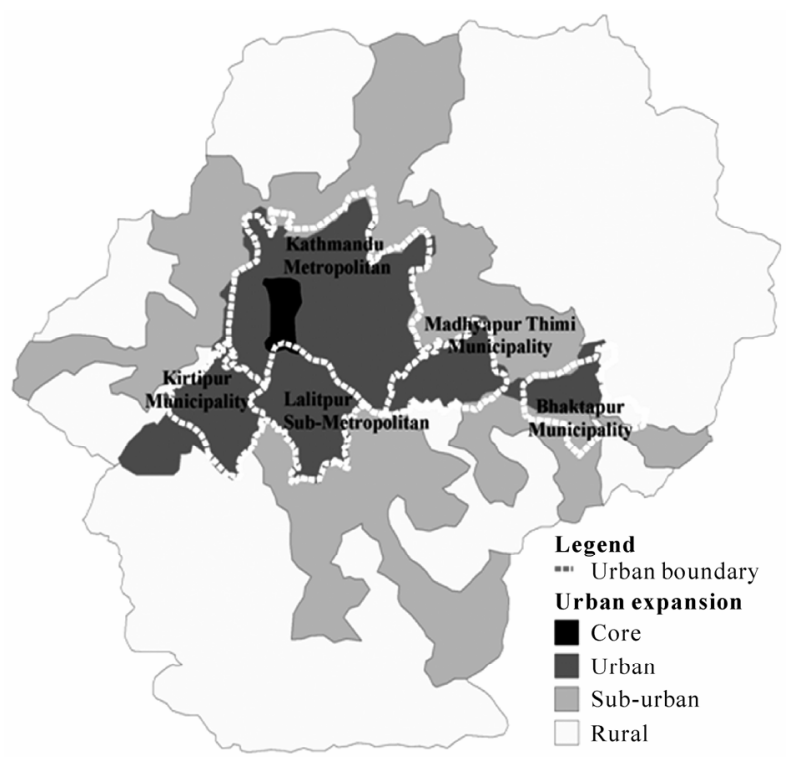

Figure 6. Urban sprawl into the hinterlands.
In the $1900 \mathrm{~s}$, Kathmandu was a small town with a little over 5,000 people [55]. In 1955, it comprised $100 \%$ of the total urban population of the country [57], and in the 1970 s, Kathmandu had slightly more than $50 \%$ of the total urban population [58] as one of 33 urban centers in Nepal. In 2008, with over 58 urban centers, the Kathmandu Valley supports over $40 \%$ of the total urban population [59]. From 1955 to 2008, the Valley's population grew over 499\% [40]. Currently, it accommodates over 750,000 people [59] and has become a macrocosm of South Asia comprised of many diverse socioeconomic and ethnic groups. Due to the unplanned urban growth similar to many other developing countries of the global South, where " $86 \%$ of the households face more than one threat" [60], contemporary Kathmandu dwellers face many risks due to unplanned structural construction practices, inadequate planning for road accesses, high population density $[59,61]$, weak institutional capacities [62] and inadequate solid waste disposal facilities (Figure 7).
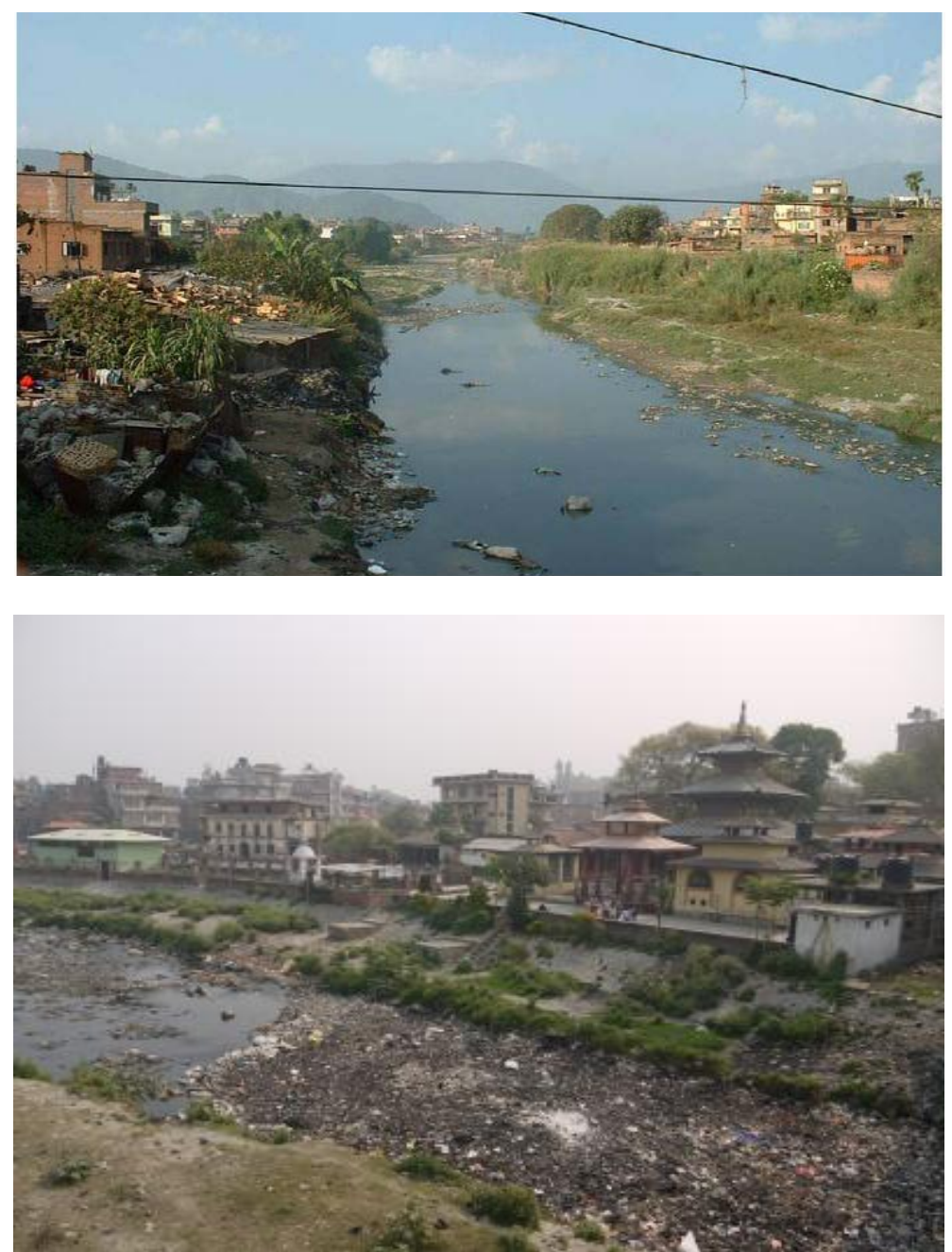

Figure 7. Problems of waste disposal (Source: http://www.kantipuronline.com). 


\section{Data}

Our data utilizes the smallest geographical units for measurement, such as the housing patterns by dwelling types, vacant land, parcel lot and home sizes, and roads. These features are digitized from IKONOS (2004), WorldView (2008), Google and ArcGlobe images of 2008 and 2010. Multicolor IKONOS 2004 images were used to digitize structures from compact urban areas, while other images were used to capture structures of newly developed and in-filled areas. Demographic data, such as the average number of households and total number of people living in urban areas was obtained from the Census Bureau of Statistics (CBS) of Nepal. Administrative boundaries of metropolitan, sub-metropolitan and municipal areas are digitized from the 1:24,000 topographic maps obtained from the Department of Survey of Nepal's Government. Due to high costs, it was not possible to purchase 3D features from Voxel Corp. For example, a scene of 100 square miles that details road network costs over $\$ 50,000$ to purchase, and $\$ 100,000$ for a scene that captures detailed urban ensembles. Alternatively, we use $1 \mathrm{~m} \times 1 \mathrm{~m}$ elevation data purchased from LandInfo (http://www.landinfo.com/) to build 3D structures of urban features. Using this data we examine population growth rates, housing densities, building plot sizes, hygienic conditions, and road accessibility to individual houses.

\section{Methods}

Urban vulnerabilities are assessed using: 1) population growth and urban density-intensification; 2) plot sizes and building structural compactness; 3) housing patterns and hygienic conditions; 4) available open spaces; and 5) emergency vehicle accessibility to residential houses.

\section{Population Growth and Urban Density-Intensification}

Population Population density of the Kathmandu Valley is increasing at a much faster rate than the overall growth rate of the country (Figures 5(a) and (b)). This growth is mostly concentrated in the urban centers (Figure 8). By 2008, the Valley's residential density grew more than 1,000 persons/ha and many new three- and four- story buildings are constructed on farmlands (Figure 5(b)) and on smaller open spaces to accommodate the increasing populations in densely built structures.

Although residential density in Kathmandu is lower than in Hong Kong ( $>4,800$ persons/ha) and Thailand $(\approx$ 2,950 persons/ha), it is much higher than in the US suburbs $(<10$ persons/ha), and is similar to Malaysia $(1,100$ persons/ha). This increase in population has in-filled many open areas in the already-emerging "concrete jungle" of the Kathmandu Valley increasing the vulnerabilities of many urban areas (Figuses 9(a) and (b)). To make matters worse, new houses are continued to be built on any available space (Figure 10).

\section{Plot Size and Structural Compactness}

Although the recommended official plot sizes in the Kathmandu Valley are similar to those in Latin American Cities (plot size $\approx 100 \mathrm{~m}^{2}$ ) which also have spontaneous settlements, such as favelas, barrios, and colonias miserias; observations from WorldView I, Google, and ArcGlobe images of 2008 reveal that many houses in the Khatmandu Valley are built on plots as small as 15 to 45 $\mathrm{m}^{2}$. Adhikari [56] observed similar conditions, and following an analysis of housing density rates and housing costs, he concluded that accommodating over 600 persons/ha in compactly built structures is not economically beneficial (Figure 11).

Despite this significant relationship between housing densities and costs, smaller plots of land are often sold by private land brokers to meet individual buyer's economic (use-value) interests, and in many cases new houses are built at substandard levels, sometimes without the basic necessities [63]. For example, many reinforced concrete (RCC) houses are constructed on smaller plots ranging from $2-4$ anas $\approx 63$ to $127 \mathrm{~m}^{2}: 1$ ropani $\approx 16$ anas $\approx 509 \mathrm{~m}^{2}$; often without proper sewage outlets [56].

\section{Housing Standard and Hygienic Conditions}

The American Public Health Association (APHA) defines housing as a "safe dwelling unit with sanitary facilities fit for human habitation by governing the condition and maintenance (1971)." Mood [64] defines housing

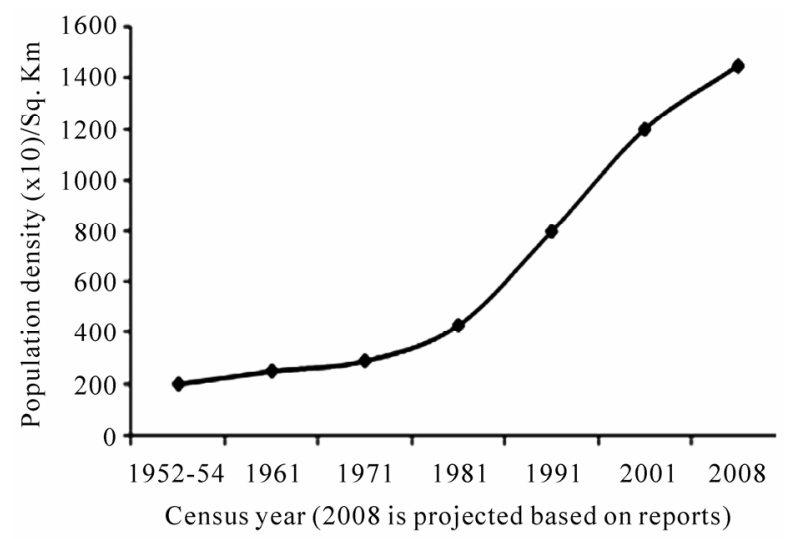

Figure 8. Urban population density. 

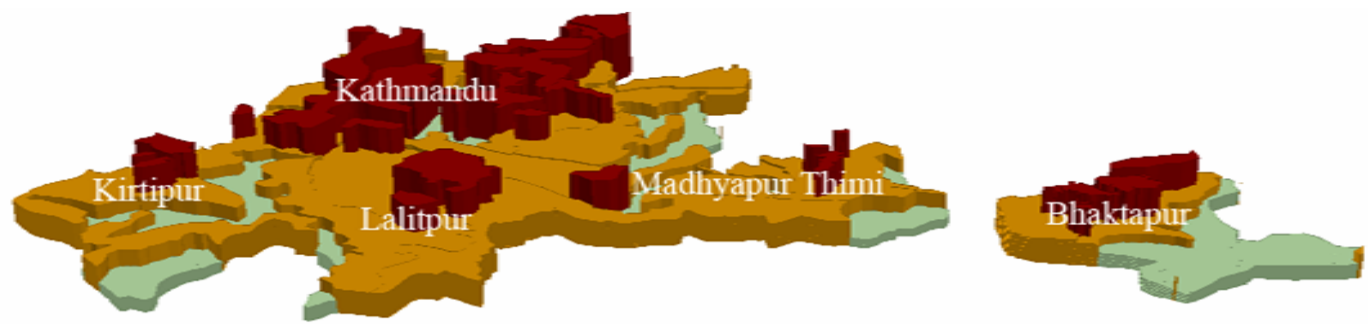

(a)

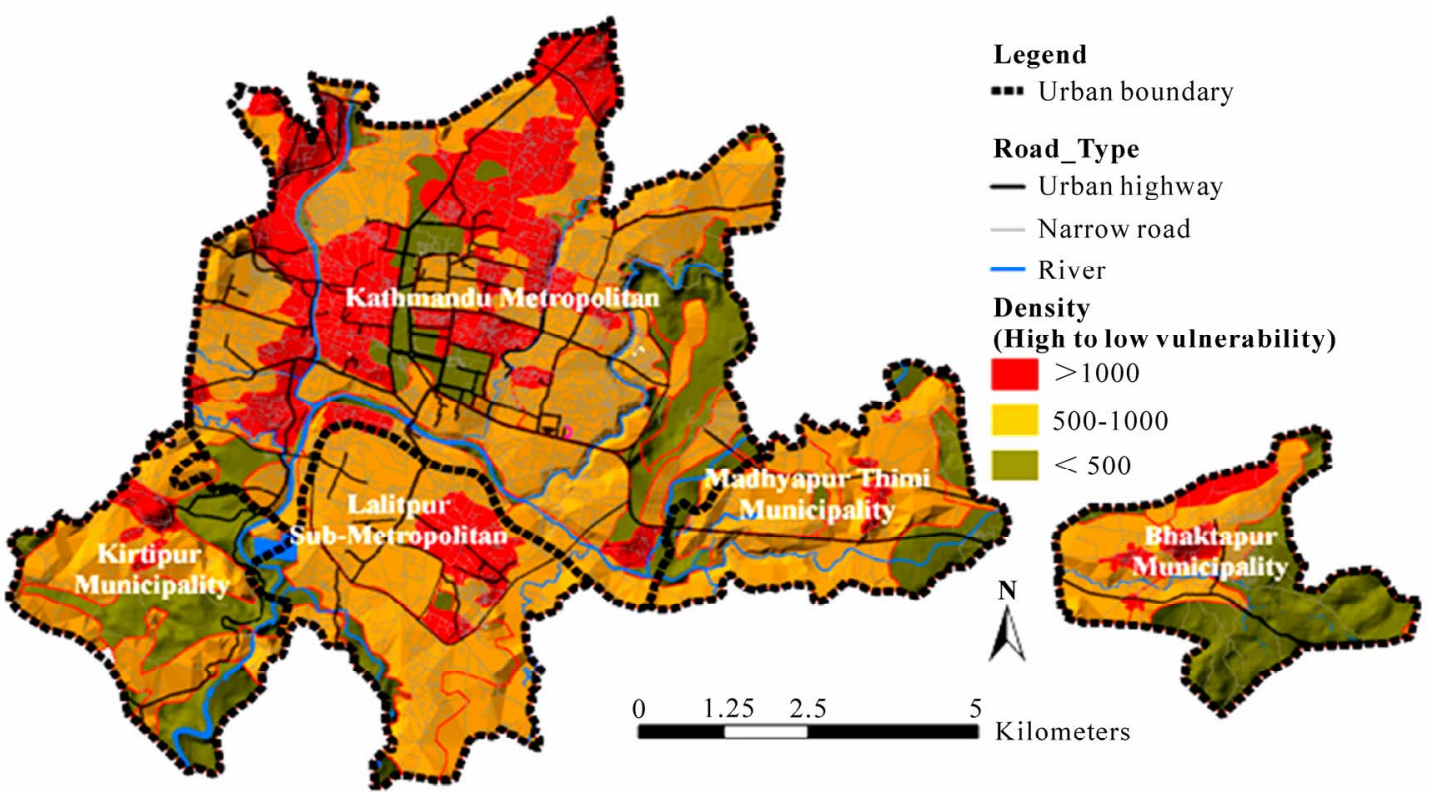

(b)

Figure 9. Visualizing (a) low and high risk housing areas, and (b) housing population densities. All compact areas are extruded in ArcScene to reveal their vulnerabilities, in the event of an earthquake.

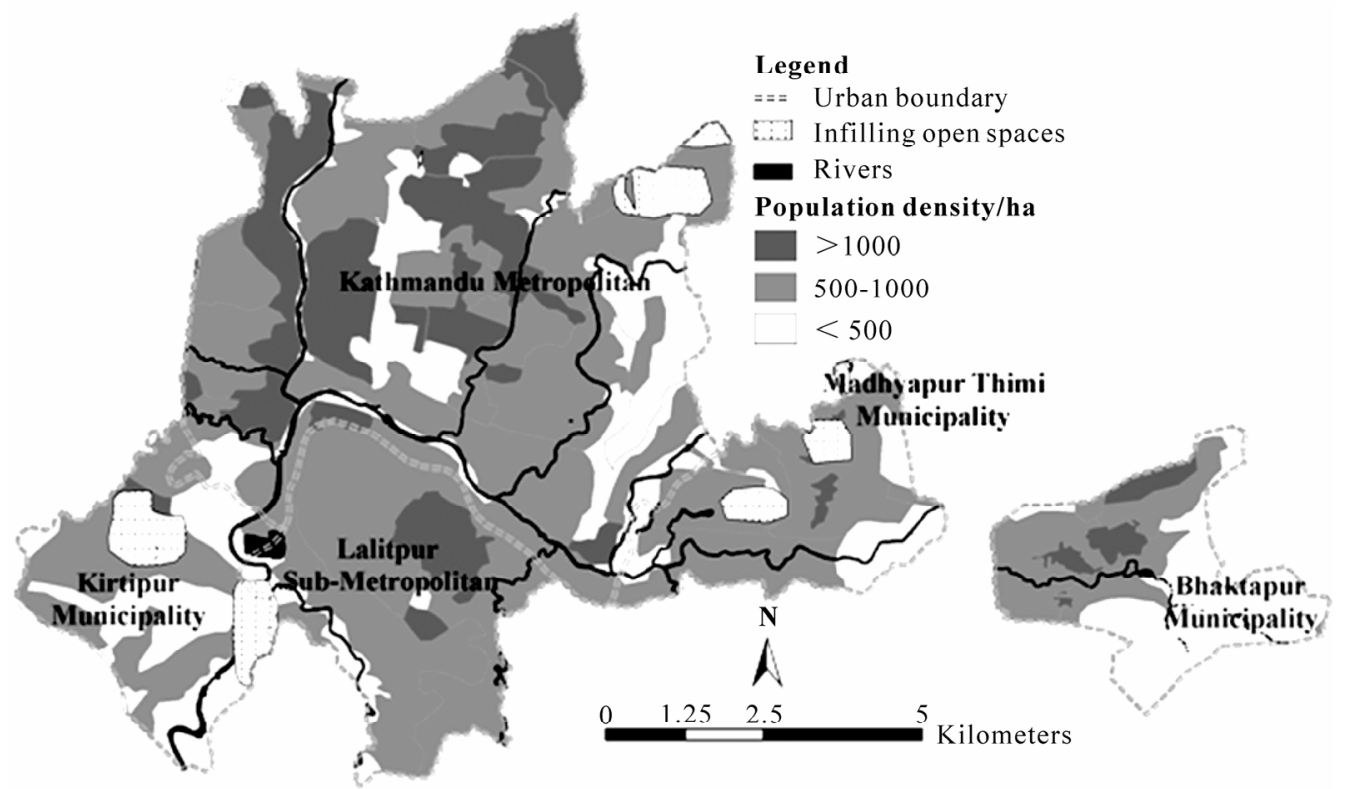

Figure 10. Infilling of built structures in the Kathmandu Valley. 


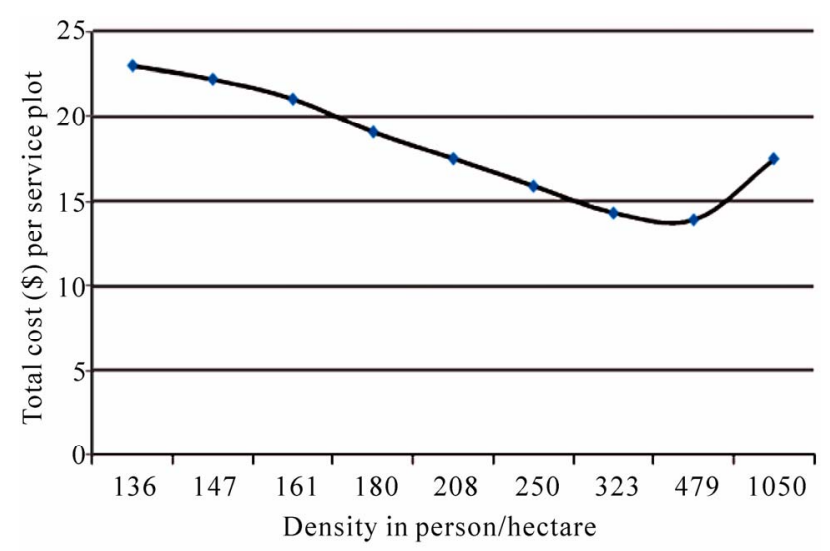

Figure 11. Plot size and cost of land (Modified from Adhikari [56] including land prices of obtained from the Land Reform Office, Kathmandu).

as "necessary to safeguard the health and welfare of the occupants of the dwelling and the persons residing in the vicinity of the dwelling." Most of the spontaneous and institutional types of houses built with local materials (Figure 3) in the Kathmandu Valley do not meet "the required health, safety, seismic scales and external environment" [56]. Many buildings are built with scant regard for regulations, such as building codes and municipal regulatory controls. Some residential buildings are constructed on $400 \mathrm{~m}^{2}$ land, occupying up to $51 \%$ of the plot with $<4 \mathrm{~m}$ from the front and back boundaries of the plot, and $<3 \mathrm{~m}$ from the sides of the plot boundary. Other buildings are constructed on plots of $200 \mathrm{~m}^{2}$ with a maximum permitted built-up area of 55\% leaving at least $3 \mathrm{~m}$ in the back and $2.5 \mathrm{~m}$ in the front. Also, within this spontaneous typology are government institutional buildings constructed on plots $>900 \mathrm{~m}^{2}$ with at least $5 \mathrm{~m}$ distance between the houses and with $7 \mathrm{~m}$ at the front and back boundaries, and $5 \mathrm{~m}$ from either side. Such modern expensive buildings with hyperbolic parabolic roofs, large concrete cantilevered beams and slabs, and concrete steel structures designed with modern engineering methods are very common on smaller plots [56]. A newly emerging architectural trend of decorating building façades with numerous "false" elements such as double columns, bay windows, and sloped roofs, often makes buildings vulnerable to earthquakes due to the lack of structural connection with the building framework. The differences in the building (and floor) heights, materials and construction technology in new constructions, are likely to produce a "pounding effect" vis-à-vis adjacent houses in the event of an earthquake [50].

Housing standards are not strictly followed, as the existing legislation is simply inadequate and ineffective to curb such practices. A house with a $30 \mathrm{~m}^{2}$ floor-space needs at least a $40 \mathrm{~m}^{2}$ plot to accommodate a family of six. The majority of the houses in the Kathmandu Valley do not adhere to these requirements. As a result, people live in overcrowded and often dangerous conditions. An analysis of residential housing units from WorldView I images of 2008, following Lo [65] model, reveals that on average, three-to-four people share a room of $12-15 \mathrm{~m}^{2}$. Small, irregular-sized houses within sturdy "housing compounds", designed for security reasons, commonly serve as garbage sites and dust bowls in the dry season and filthy-water ponds during the rainy seasons. This problem is further exacerbated when seepage from individual septic tanks leaks through the residential compound walls that interface with and front adjacent narrow roads [56]. Additionally, drinking water pipes often follow the narrow winding streets and run parallel to sewage pipes making service maintenance difficult [63].

Sub-standard, yet often exorbitantly-priced housing has increased property and land prices, making most housing unaffordable to the common Nepalese and leaving them with no other alternative but to squat on open lands. A comparative assessment of the IKONOS 2000, Quickbird 2003, WorldView I, Google and ArcGlobe images of the Valley taken in 2008 reveal the mushrooming of spontaneous slum settlements along the riverbanks and open spaces (Figure 12), [52]. These houses are constructed along the ecologically sensitive and marginal areas, such as riverbeds and lowlands, and along dangerous or untenable flooding areas without proper access to clean water. In most instances, these houses are not accessible by motor vehicle. Furthermore, squatters often occupy national heritage sites such as temples and monasteries $[66,67]$, or live near waste-dump sites, making them extremely vulnerable to life-threatening events and conditions.

Many houses in the Kathmandu Valley store garbage in large polythene bags, which are then thrown outside to lie uncollected for long periods of time in the adjacent open areas. This practice of open dumping is not only unsightly, but also serves as a breeding ground for diseases, posing a constant health hazard for the surrounding population. Many dumpsters or garbage collection sites are close to sensitive ecological areas, such as drinking water sources. Thus, these effluent discharges pose health challenges [68] from the daily discharged waste $\left(1091-1155 \mathrm{~m}^{3} /\right.$ day or $245-260$ tons/day in the valley). Waste is not collected from dumping sites on a regular basis due to opposition from landfill sites. Similar to the case in Mexico City where garbage disposal has become an effective political tool [69], garbage disposal in the Kathmandu Valley is not only a political tool, but has also made living conditions more difficult by creating new health hazards. The situation becomes much worse as new consumer products-many with unnecessary packaging, plastics and styrofoam-enter into Kathmandu's "modernizing" market every day. The protestors of the landfill sites often agitate against the municipal authorities like those that occurred in Philadelphia (1986), New York City (1990), Toronto, Ontario 


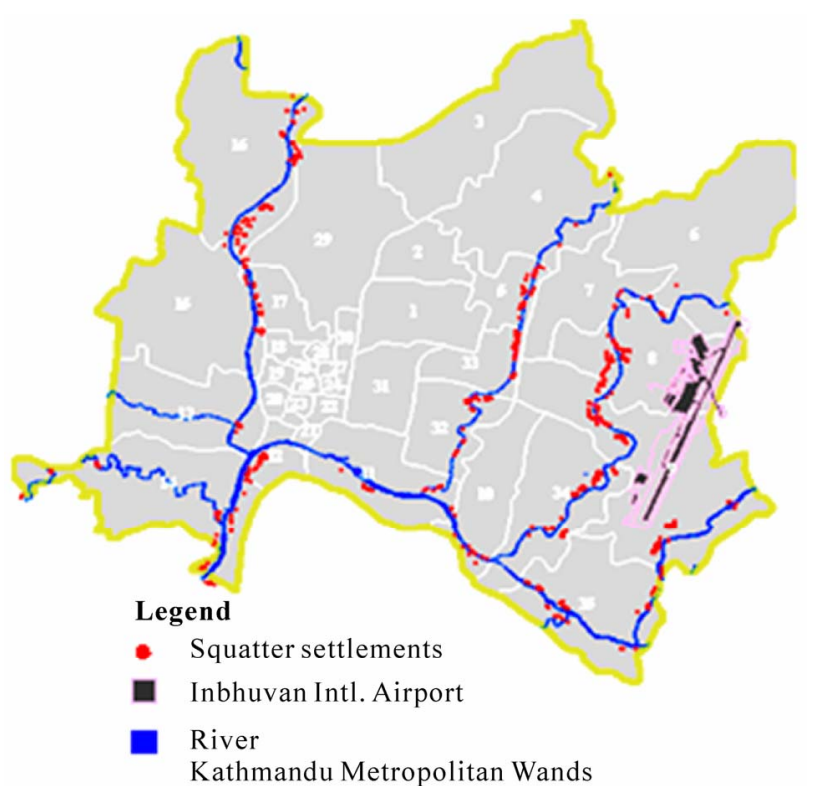

(a)

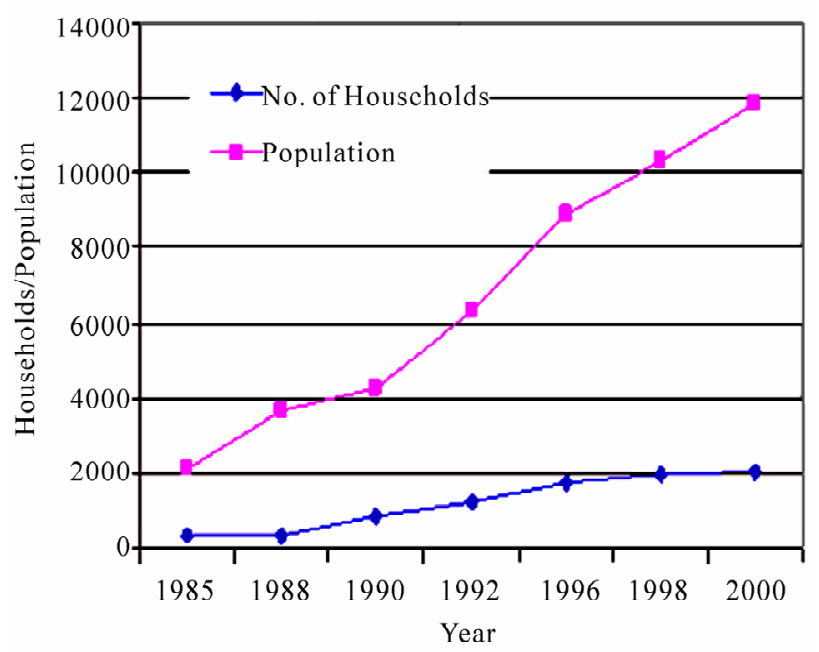

(b)

Figure 12. (a) Locations of squatter settlements along the low level river banks (Pradhan \& Perera) [52]; and (b) number of households in different years (http://emi.pdc.org/ cities/CP-Kathmandu-08-05.pdf).

(2002), Chicago (2003), Vancouver, British Columbia (2007), Athens, Greece (2006), Alumfiecer, Spain (2007), Naples, Italy (2008), and Oaxaca, Mexico (2009) (Moore, [69]. In the Kathmandu Valley, the more unorganized the garbage management becomes, the more it becomes a political act. Similar to Castro-Gomez's [71] call for an "ideal of synthesis" between science, economic growth, and aesthetic development (p. 139), some local Valley political parties consider debates related to garbage disposal as a Marxist "dialectic discourse." As the dialogue goes, dumping garbage on the available open areas has become a practice of Kathmandu's dwellers.

\section{Open Spaces}

Each household needs some open space for a healthy environment and an escape-route to safety in the event of a disaster. An open space is defined as the ratio of circulation area divided by the total area that is specific to cultures and places. Parks and playgrounds, schools and colleges, hospitals, public transportation, telephone lines, sewers and discharge pipes are considered open spaces. Caminos and Goehert [72] recommended an open area of $150 \mathrm{~m}^{2}$ per $10,000 \mathrm{~m}^{2}$ of built-up area, while the World Bank housing project recommends 20 to $25 \%$ open space for a built-up area. For the safety of an individual, a $2 \mathrm{~m}^{2}$ space is needed. In general, $5-10 \%$ open space is needed for housing purposes; however, the unplanned housing schemes in the Kathmandu urban areas leave few open spaces producing conditions far below any Western standards. Even in Manhattan, New York, an average of $19.2 \mathrm{~m}^{2}$ of natural area is available for each skyscraper; in London, the number is $30.4 \mathrm{~m}^{2}$ for each building accounting for the city's surrounding Green-belt spaces; in Paris, it is $12.2 \mathrm{~m}^{2}$; and in Tokyo, it is $2.1 \mathrm{~m}^{2}$ [70].

These aforementioned numerical values of "open space", however, may not be the best measures when evaluating "accessibility" and its efficiency and cost- effectiveness as it pertains to a metropolitan area's housing growth and development. For example, only $12-16 \%$ open spaces are maintained in Singapore, but all houses are accessible by emergency vehicles. Nonetheless, for cities like Kathmandu to serve 2- to 4-story spontaneous and institutional housing styles, sufficient open spaces are needed to rescue people from possible seismic vulnerabilities. Given the seismic vulnerability of the Valley, contemporary planners in the Valley suggest a 40:60 ratio, for built-up and non-built-up land, by 2021, which will be higher than the 32:68 ratio that planners envisioned in 2001. A detailed analysis of the Kathmandu Metropolitan area from the WorldView I, Google, and ArcGlobe images of 2008 reveal that it is almost impossible to meet this goal given the diminishing number of open spaces resulting from the infilling of housing in small open spaces (Figures 5(b) and 10). Additionally, the loss of open spaces and vegetation (Figure 5(b)) due to conversions into sub-standard buildings, has not only hindered vehicular accessibility to houses, but also has made the bowl-like geography and generally low wind- speed valley, become a sink for pollutants during the winter seasons [42].

\section{Road Accessibilities}

The The UN has long defined a housing standard as a "measure of accessibility, at a given time and place and in a given set of cultural and economic conditions" (73: p9). For good connectivity and the movement of people 
and goods, both within urban areas and between urban centers and hinterlands, effective transportation networks are essential. However, narrow streets and cul-de-sacs limit vehicular accessibility to individual houses. A classic example of the "Tragedy of the Commons" is evident in Kathmandu, due to individual households' thoughtless efforts to maximize the private use of their entire property, at the expense of the common good [56]. In the inner areas of the Valley's city centers, the narrow streets ( $\leq 2.5$ meters) and sturdy wall fences erected for security reasons are posing problems of accessibility (Figure 13). In the absence of sufficient rules and/or the lack of implementation, inner-city land plots have been subdivided to maximize profits, and such action has further narrowed the width of roads.

Western-style suburbs with large open spaces are unavailable in the Kathmandu Valley due to high population to land ratios, and the preponderance of low income conditions among a majority of residents. In western countries, roads are categorized by their widths and services they provide; for example, collectors ( $8 \mathrm{~m}$ width, serving over 150 houses with 10.5 right-of-way), secondary (6 m width, serving at least 15 houses with 10.5 right-of-way), and local (4 m width, serving 25 houses with $5 \mathrm{~m}$ right occur.

\section{Patterns of Vulnerability and Resilience across Urban Areas}

In Nepal, urban vulnerabilities are the result of poor planning. Local planners routinely deal with issues of slums, squatters and low-income housing, and overburdened infrastructure issues, not to mention the problems of working within a corrupt political and inefficient bureaucratic environment. Politicians routinely get their votes from the slum and squatter dwellers and keep planners and bureaucrats engaged with immediate problems rather than having them find long-term solutions [5]. Many planning decisions are made administratively, which are often influenced by backroom political pressures. Even when a physical plan is finally approved, individual builders often build their own projects in an organic fashion (unplanned) that routinely result in haphazard growth [5]. Because of such unregulated urban planning, quality of life issues such as the environment and social sustainability, rarely make it on to the agendas of the Valley's urban planners.

Planners have been dealing with the complexities created by the ever-changing societal needs, market and economic forces, and conflicting interests among various stakeholders. Mitigating urban vulnerability in such environments is difficult, and planners routinely experience a "planner's fatigue and burn out" from their work [5]. Though planners may attempt to achieve their goals with highly engineered processes, engineering alone will not solve problems such as jammed road networks (Figure 13) and poor accessibility (Figure 14).

Accessibility needs to be given the highest priority, because it is not only important for business but also to evacuate people in cases of emergency. Unfortunately, the occurrences of accidents, vehicle breakdowns, road closures due to road works and political agitations are

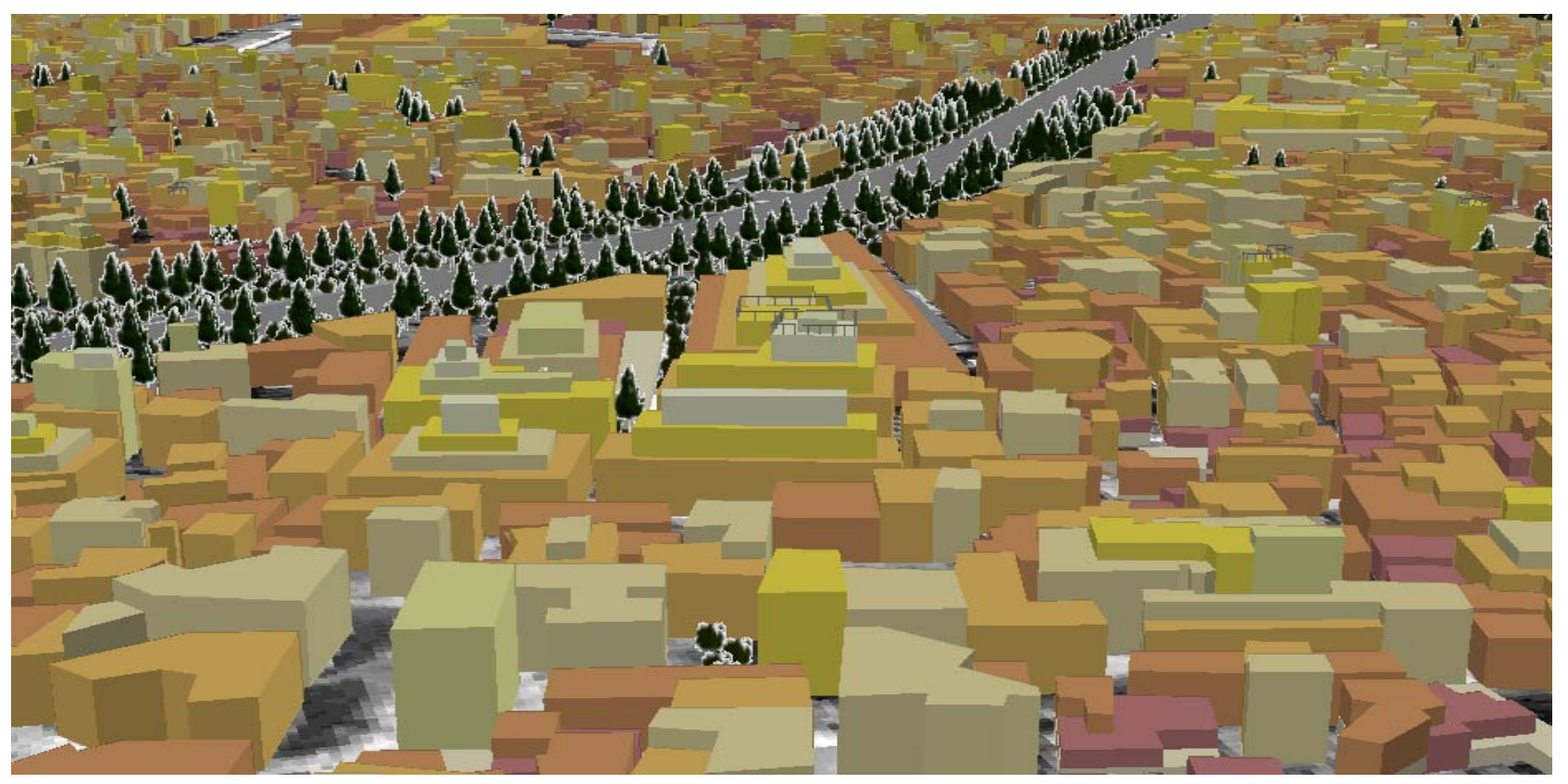

Figure 13. 3D visualization of housing typology without proper accesses by emergency vehicles (New Baneshwar area of Kathmandu digitized and converted into 3D). 


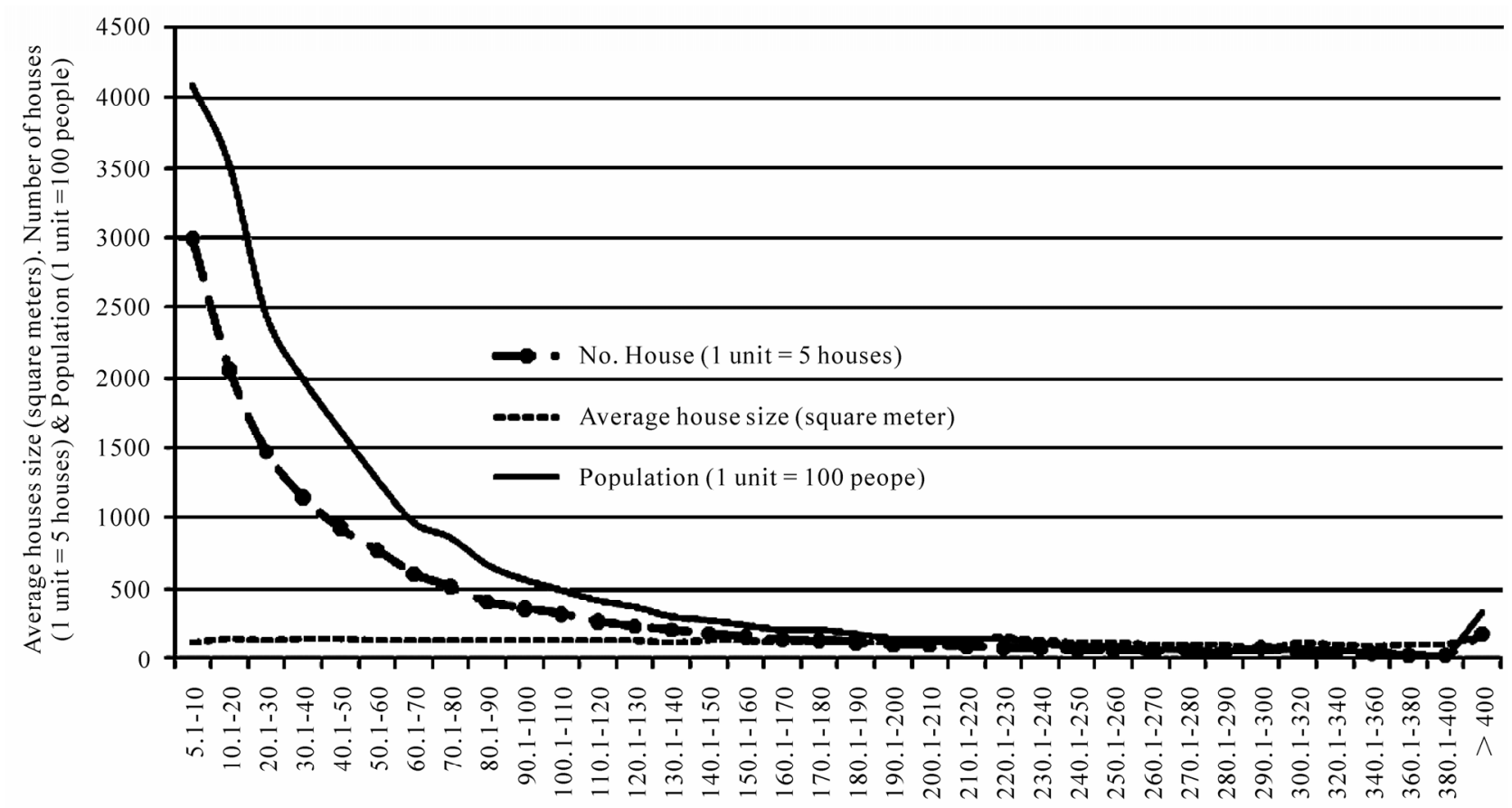

Houses accessible distances (meters) by emergency vehicle

Figure 14. Distances to individual housing units from serviceable roads. Average plinth areas of houses were estimated from WorldView I and Google images of 2008, population for each housing dwelling unit was estimated following Lo (2006) “Dwelling Unit-related Demographic Models" (p. 351).

common problems on narrow roads. Despite traffic jams on narrow roads, more vehicles are registered than the transportation network can accommodate. For example, over 181,000 new vehicles were registered during 2005-2008 [74], but only a very small increase in road length was added to the existing 1,319 kilometers of road length over the same period. Each year, many houses are added by filling-in open spaces (Figures 5(b) and 10). Politicians often favor their constituencies and pressure bureaucrats and planners to add more urban ensembles, in order to demonstrate their short-sighted promises made during the election periods. Political leaders often make false promises while campaigning when the mass gatherings of their supporters prompt such political pandering. Planners then bow to the pressures of these politicians, letting building code standards and their general plans go by the way side.

The $3 \mathrm{D}$ visualization techniques we use and advocate therefore may help planners to effectively visualize the cities (Figure 13) they are responsible for; and ultimately, convince them to implement more eco-friendly and sustainable policies [75]. Currently, these 3D data models are being developed on smaller scales, which are helpful when dealing with boundaries, neighborhoods, and co-boundary cells [30]. In order to display the topological relationships for large-scale areas, Chalmet et al. [76] developed a 3D graph model. Instead of representing the topological relationships between node, arc, face, and body, these graph models present the topological relationships among 3D objects [77] and 2D objects. These models represent the adjacency, connectivity, and hierarchical relationships among buildings and street networks to provide navigation guidance for an escape. Acquiring accurate location information is challenging as many buildings block GPS signals, however, geocoded addresses may help to accurately locate spatial objects.

In such a 3D model, geocoding converts descriptive location information into geometric coordinates. The geometric coordinate information can be applied in the $3 \mathrm{D}$ for route finding problems by identifying the shortest path from a single source to all other nodes in a network. It utilizes multi-layer building morphology data, shapefiles, digital elevation models (DEM) data, and remote sensing data to develop a complex 3D city model. Such $3 \mathrm{D}$ city models can be utilized to analyze a variety of parameters including building occupancy, frequency values and socio-demographic patterns that highlight areas and objects exposed to various levels of threat. By combining function-specific grids with 3D exposure levels, we map potential threat areas. These specific threat levels can be combined with additional socio-demographic or infrastructure data to further geo-visualize risk prone and safer areas to alleviate urban congestion. 


\section{Alleviating Urban Congestion to Minimize Vulnerability}

We identify urban vulnerabilities in the Kathmandu Valley resulting from unplanned developments with irregular, substandard, and inaccessible (by emergency vehicles) housing patterns, coupled with waste disposal problems. Approaches taken by the past governments to alleviate urban congestions outside the Kathmandu Valley, such as, "Creation of Five Regional Divisions and Decentralization of Power," and "Relocating Educational Institutions" have unfortunately failed. None of them have successfully relocated any of the burgeoning urban population away from the urban concentrations in the Valley and none have reduced, or even satisfactorily addressed the unpredictable urban sprawl and growth.

Urban sprawl (unplanned growth) and growth (planned growth) often happen during economic booms, but in the Kathmandu Valley, rapid urban sprawl and growth occurred as the Maoist insurgency escalated in the countryside beginning in 1996 . The threatened rural people responded by migrating into the Valley for safety. As a result, the lack of any planning is exaggerated, leading to inappropriate land-use, increased traffic congestion, persistent and increasing emissions of green house gases, longer commute times for shorter distances, increased dependence on imported goods and fossil fuels, worsening water pollution, loss of open space, unmanaged waste disposal, political upheavals, road network overloads and institutional "grid-lock".

There are cities such as Las Vegas, where a $238 \%$ urban growth occurred between 1990 and 1996 [78]. However, Las Vegas is comparatively "well planned", whereas Kathmandu Valley is growing organically despite experiencing a slower growth rate than Las Vegas. Long overdue in Valley planning logistics is a need to not only reduce traffic jams and to conserve open spaces, but also contingency plans and infrastructural re-alignments that will enable the authorities to evacuate people in the event of a high intensity earthquake like that of 1934 in Kathmandu and of January 13, 2010 in Haiti. Kathmandu's seismic condition is as vulnerable as that of Haiti. While earlier it was firmly believed that rapid urbanization would bring increased development, now, it is time to weigh the values of safer and healthier communities and green space against the consequences of unbridled, development. There is an urgent need to reverse the process of urban congestion through counter migration by decentralizing many power centers from Kathmandu to elsewhere. Limited open spaces of the Kathmandu Valley are today occupied with in-filled infrastructures with inadequate, poorly-constructed housing, and deteriorating local environmental conditions. In the foll population might be resettled and moved owing paragraphs we present various options on how the Valley to other areas.

\section{Strict Imposition of Building Codes}

Urban vulnerability in the Kathmandu Valley is due to physical events (seismic hazards) and societal conditions (substandard house and unplanned layouts). Though seismic hazards are very dangerous, socioeconomic and political systems play even a larger role in creating vulnerabilities for the population. As these natural processes cannot be changed, the practical solution is to address the hazards resulting from socioeconomic and political systems. In most parts of the Kathmandu Valley, buildings stand side-by-side on narrow alleys. Fire brigades and ambulances are unable to provide services (Figure 14) [79] and in the aftermath of a big earthquake, it will be difficult to provide emergency services due to the accumulation of debris on narrow roads. Even hospitals, schools and public offices are not earthquake-resistant [47]. Public awareness about earthquake safety, enforcement of building codes, and proper training of masons to build standard houses is essential. In the Kathmandu Valley over $90 \%$ of the houses are built by masons, however, only $10 \%$ are supervised by trained engineers [47]. Many engineers are needed to ensure an effective implementation of building codes for the safety and security of the Valley residents.

Nepal has acknowledged the need for earthquake safety measures-especially after the International Decade for Natural Disaster Reduction (1990-2000) and has initiated various strategies at the national level including retrofitting of schools, preparation of emergency hospital plans, and conducting training sessions to address the challenges faced in the aftermath of an earthquake. However, these plans have become paper tigers. For example, the 1995 Kobe earthquake in Japan, has clearly demonstrated that preparedness and emergency plans in hospitals alone are insufficient if it is not possible to keep equipments, staff and electricity running during an emergency. Learning lessons from the recent Haitian disaster is essential. Additionally, strict quality control on construction work and building materials including bars in slabs and columns is essential [50].

On the development front, a combination of disasterrelief programs and responsible (re)development techniques need to be introduced and implemented through flexible means of incentives, consensus, and awareness programs, rather than by rigid laws. On the legal and institutional front, an independent disaster management institute managed at the federal level and backed by legislation to formulate earthquake mitigation techniques, emergency response plans, and post-reconstruction programs to coordinate various concerned agencies is essential. The community's preparedness could be improved by retrofitting the existing buildings, developing rescue and response plans, and educating and training those involved in the building industry. Such efforts, together 
with increased public awareness at the household level could help develop a culture of building earthquakeresistant cities and disaster-responsive societies. Once individual households are made aware, it will be possible to develop model houses (Namuna Gharharu) that preserve the traditional architectural styles recognized by UNESCO.

\section{Conserving Urban Spaces}

In many developed economies, a number of communities are now purchasing environmentally sensitive land or farmland to prevent uncontrolled development. However, such an approach is not feasible for the Kathmandu Valley due to the high cost of land. Also, unstable political conditions do not support such moves. Nonetheless, the government can enforce laws to prevent the building of substandard houses on open spaces.

While such a law has been passed recently, the outcome of this rule is yet to be seen. Another example Nepal can learn from is the Communist government of Vietnam's decision in the 1970s to ban rural-to-urban migration. In 1949, the Chinese government strictly enforced and restricted in-migration by implementing stringent residency permits to control rural in-migration to the biggest cities. Limiting the number of citizens who could be registered as urban dwellers restricted the number of individuals moving to cities to find better jobs. The registration program was supported by the rationing of food only to those in possession of urban household registration documents. In the absence of any significant black market, these measures proved highly effective in slowing the rate of rural emigration [80]. Such approaches could be implemented in the Valley to stop further overcrowding and minimizing urban vulnerability and even improving city efficiencies and aesthetic conditions.

\section{Improving Urban Efficiency}

Kathmandu's urban patterns, its socioeconomic status, and demographics are a challenge to the successful implementations of innovative (re)development plans. However, some experiences from other countries could be helpful in improving the cities' efficiencies. One such approach-Haussmannization (named after Baron Haussmann, a Paris-based urban planner of the 1940's) - was followed by the French government to improve the cleanliness and appearance of Paris streets. Roads were widened roads and proper buildings were realigned. The US government in the 1950 s and 1960 s, implemented urban renewal plans backed by billions of dollars to dismantle old buildings and properly realign them along improved roads and housing patterns [81]. Likewise, in the $20^{\text {th }}$ century, a social equity plan was implemented in
New York City, USA. This plan allowed only a certain percentage of any given lot to be occupied by tenement buildings and strict building codes were followed. Such buildings provided much needed facilities to renters [81]. The Chinese government took a different approach to control urban congestion. When the Communist Party assumed power in 1949, many people were living in terrible slums. Cities were filthy with inadequate sewage facilities, water supplies, and garbage collection. The Communist government dramatically altered the Chinese cities by cleaning them up and providing standard housing for everyone. Rural-to-urban migration was strictly regulated. While the Chinese approach per se might not work for Nepal due to a different government system, cleaning the cities as was done in China, and regulating rural-to-urban migration would help to improve the city's efficiency, and control urban over congestion. A zoning method practiced in Frankfort, Germany in the late $19^{\text {th }}$ century was used to control land use based on land suitability classes [81]. In capitalist economies these programs are self-sustaining financially, where the governments first purchase the lands and do planning to improve efficiencies, and then resell the lands at higher costs. Though some of these approaches may be possible for the Kathmandu Valley, substantial foreign aid is required. While it may sound unrealistic to look for foreign aid to dedicate to internal city planning, significant improvements could be made with foreign aid to prevent potentially disastrous conditions such as those in Haiti following the 2010 earthquakes. Nepal will need foreign aid to improve city efficiency. It is a matter of time- now or later after the destruction. Along with the improvement of city efficiencies, shifting Kathmandu's over crowded population elsewhere by creating new cities and shifting the country's only international airport to other location and/or creating new international airports in other parts of the country could be some of the options to alleviate Kathmandu's urban vulnerability.

\section{Creating New Satellite Cities}

Like the cities in the Kathmandu Valley, Cairo, Egypt became overpopulated, woefully deficient in urban services, and had a high unemployment rate beginning in the late 1960s. In an attempt to improve conditions in the city center, the Egyptian government began creating new towns and jobs outside Cairo [81]. Implementing a similar plan, the Nepalese government developed Five Development Centers, namely Eastern, Central, Western, Midwestern, and Far Western in the late 1970s. Unfortunately, these centers did not attract citizens due to the highly centralized power structure of the Nepalese government. The 1970s approaches failed to attract people away from Kathmandu due to a lack of planning and organization. Following the formation of the multi-party 
democracy in Nepal in 1990, several universities, technical institutions, and medical facilities were opened outside the Kathmandu Valley with the hope that new cities would be created and the Valley's population pressures would decrease. To some extent this approach has been successful in attracting businesses due to the low cost of land and proximity to several Indian cities near the southern border. However, these cities have failed to attract a higher number of residents due to a lack of job opportunities and inadequate access to international markets. To make matters worse, beginning in the late 1990 s, security in virtually all of the cities outside Kathmandu was compromised as a result of the Maoist insurgency. Improving transportation to create increase connections between these outer cities and Kathmandu may help to improve security and ultimately facilitate out-migration from Kathmandu or even to daily commute to Kathmandu for official work. Several European countries have successfully reduced the overcrowding and traffic jams in urban cores by implementing various transportation policies and facilitating people to commute by public transportation services.

\section{The Western European Transportation Model}

Several transportation models adopted in European countries have been successful in alleviating traffic jams in the main urban areas. For example, the cities of Bergen in Norway have successfully decreased traffic by $7 \%$ with the introduction of a Kr. 5 (\$0.80) toll per vehicle, per day, for entering the city center. A similar approach in Oslo minimally reduced traffic by $3 \%$ despite a higher Kr. 10 (\$ 1.60) per day, per car [82]. In Singapore, a similar approach successfully reduced traffic congestion. The low rate of success in Oslo may be attributable to lower price elasticities, due to the lack of transportation alternatives available to the motorists for long-distance trips.

In Central London, a charge of $\$ 1.00$ per day reduced automobile traffic by $45 \%$ and increased speeds by $40 \%$, and the benefits were estimated at $\$ 50$ million per year. Approximately, $15 \%$ of the revenues were used to pay for the enforcement and administration of the plan. This improvement in traffic reduction was possible with the reinforcement of other policy improvements such as rail infrastructure, bus service, park and ride provisions, and environmental traffic management [82]. The 40\% decrease in car traffic has resulted in reduced fuel consumption and a $15 \%$ reduction in carbon dioxide emissions. However, the introduction of such a system raises the question of how to equip vehicles with a levy system to ensure payment [83], as well as issues of privacy and freedom of travel [84]. Low income travelers supported the idea of charging taxes to private vehicle owners [85].

Other measures that can be applied to control traffic include: 1) parking control, 2) physical reallocation of road space, and 3) regulatory controls using permits or other restrictions on car use. The practice of reallocating road space to other users, such as buses, failed in Nottingham, UK, in 1975 due in part to an increase in the cost of bus travel [86]. Yet in several Italian cities, grant permits were needed to enter certain zones, and in Athens, Greece, an "odds and evens" scheme was implemented in which odd-numbered cars were allowed into the city center on alternate days of the week and even-numbered cars on the others. Such schemes can, in principle, achieve any pre-specified reduction in car use. However, there are possibilities of producing fraudulent permits, and a simple scheme such as "odds and evens" is not guaranteed to allocate road space to those who most need it. In Nepal, when government car plates are converted into private plates and vice versa, such an "even and odd" number approach could fail easily. Athens also adopted a complex traffic checking process using electronic barriers in which a machine would detect a certain vehicle and would raise a barrier to stop a car from crossing into a certain area without paying a levy [87].

Given the unruly state of the Kathmandu Valley, where almost every day roads are jammed as the result of a minor car accident or political demonstrations, the models discussed above may not work without maintaining strict law and order. In the late 1970 s, a ring road was built in the core peripheral areas, which at first reduced core area traffic. Currently, almost all of the areas of the old ring road are filled with new structures. The opening of a new ring road in the hinterlands of the Kathmandu Valley (Figure 15) may help to alleviate the Valley's core congestion problems for now, but the situation may very well repeat itself unless other regulatory measures are implemented. Significant changes in regulatory power, including 3D methodological assessment and enforcing building codes to ensure optimal road development is a recommended forward-looking policy. Such an approach would create the opportunity for the gentrification of neighborhoods, urban renewal, mixed land use development, and restoration of heritage sites.

\section{Conclusions}

In this paper, we have: 1) analyzed the spatial arrangements of houses in the Kathmandu Valley and identified areas with high, medium and low risks, based on the spatial arrangements of houses; 2) visualized urban ensembles in 3D views for some selected urban areas and explained how these crowded cities with sub-standard houses may prove fatal, if there is a disaster similar to the earthquake of 1934 and/or similar to that of Haiti in January, 2010; 3) analyzed the accessibility scenarios to different locations and found that many of the housing units are not accessible by emergency vehicles; and d) 


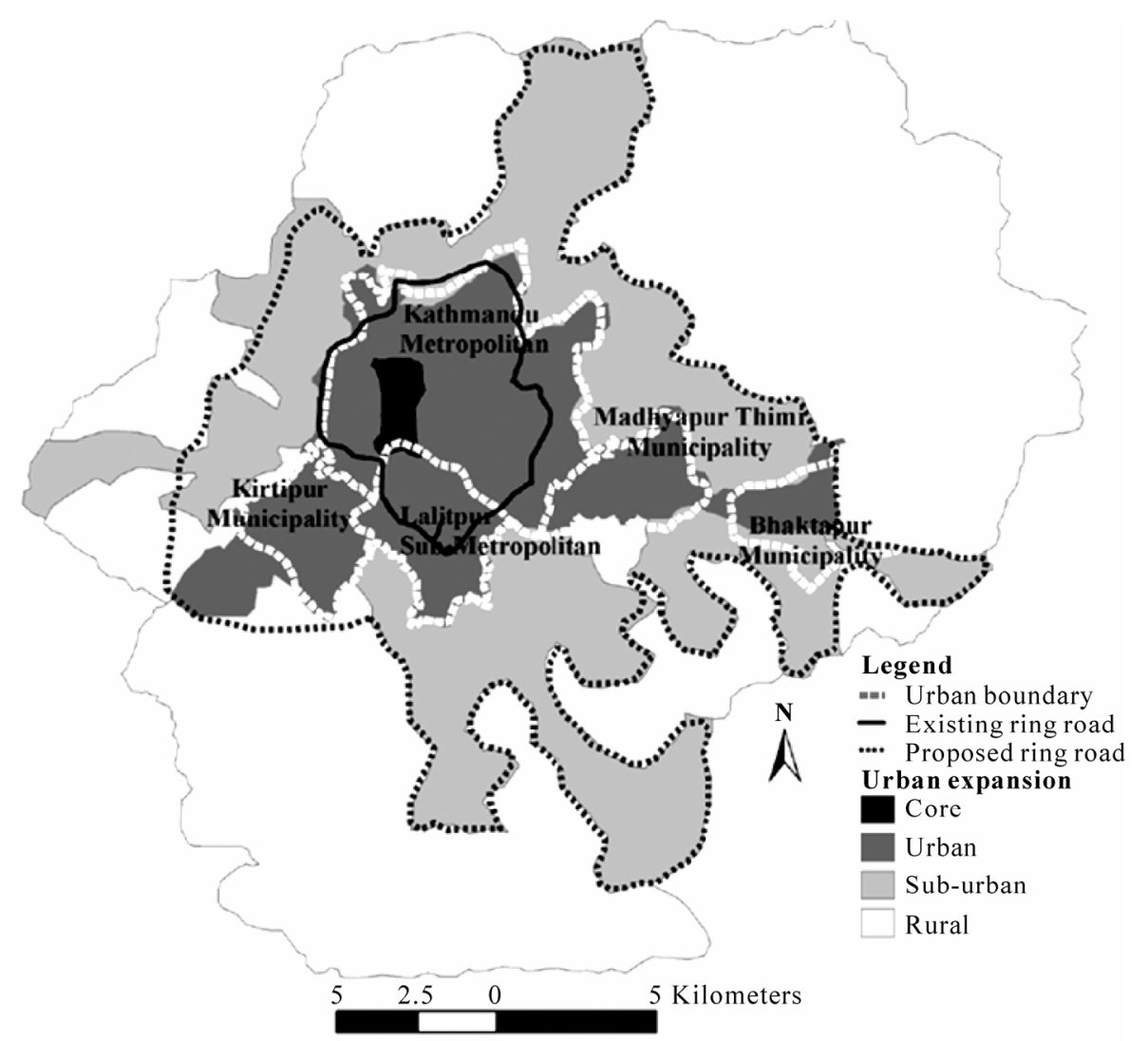

Figure 15. Proposed ring road in the Kathmandu Valley to depopulate urban core.

explained the merits and demerits of $2 \mathrm{D}$ and $3 \mathrm{D}$ data models to visualize transportation networks and a 3D road network to undertake vulnerability analysis. We conclude that without improving housing spatial distribution and the transportation network, urban vulnerabilities are likely to increase. In summary, we have identified vulnerabilities; second, we have analyzed divergent perspectives on urban vulnerability in order to test related theories and hypotheses to improve our understanding of the linkage among various urban ensembles and vulnerabilities; third, we have explained how important it is to work for integrated solutions to alleviate urban congestion; and fourth, our approach of 3D visualization of urban ensembles should help to accurately evaluate and quickly implement emergency response plans to reduce the risks to the affected urban populations following a natural disaster. Developing geospatial data in 3D will help to analyze emergency situations, and also offers spatial analytical and modeling capabilities to facilitate better planning and decision-making. We believe our paper's approach will lead to a better understanding of the dynamic nature of urban ensembles in such overcrowded urban core areas like the Kathmandu Valley, and will add to the spatial-scientific evidence that is necessary to improve planning and the implementation of solutions. One methodological limitation of this research, discovered while con- ducting our $3 \mathrm{D}$ data analyses, is that we were unable to accurately locate all objects/evacuees at certain specific locations, because GPS does not work efficiently within multi-level structures due to degradation or loss of signal in certain areas/parts of such buildings and locations. In our future research we will attempt to address this methodological conundrum.

In this paper, we have: 1) analyzed the spatial arrangements of houses in the Kathmandu Valley and identified areas with high, medium and low risks, based on the spatial arrangements of houses; 2) visualized urban ensembles in 3D views for some selected urban areas and explained how these crowded cities with sub-standard houses may prove fatal, if there is a disaster similar to the earthquake of 1934 and/or similar to that of Haiti in January, 2010; 3) analyzed the accessibility scenarios to different locations and found that many of the housing units are not accessible by emergency vehicles; and 4) explained the merits and demerits of 2D and 3D data models to visualize transportation networks and a 3D road network to undertake vulnerability analysis. We conclude that without improving housing spatial distribution and the transportation network, urban vulnerabilities are likely to increase. In summary, we have identified vulnerabilities; second, we have analyzed divergent perspectives on urban vulnerability in order to test re- 
lated theories and hypotheses to improve our understanding of the linkage among various urban ensembles and vulnerabilities; third, we have explained how important it is to work for integrated solutions to alleviate urban congestion; and fourth, our approach of 3D visualization of urban ensembles should help to accurately evaluate and quickly implement emergency response plans to reduce the risks to the affected urban populations following a natural disaster. Developing geospatial data in 3D will help to analyze emergency situations, and also offers spatial analytical and modeling capabilities to facilitate better planning and decision-making. We believe our paper's approach will lead to a better understanding of the dynamic nature of urban ensembles in such overcrowded urban core areas like the Kathmandu Valley, and will add to the spatial-scientific evidence that is necessary to improve planning and the implementation of solutions. One methodological limitation of this research, discovered while conducting our 3D data analyses, is that we were unable to accurately locate all objects/evacuees at certain specific locations, because GPS does not work efficiently within multi-level structures due to degradation or loss of signal in certain areas/parts of such buildings and locations. In our future research we will attempt to address this methodological conundrum.

\section{Acknowledgements}

This research was supported by the University Research Grant from the Office of Sponsored Programs and the College of Arts, Humanities, and Social Sciences at the University of Central Missouri (19-SU003). Special thanks go to Prof. Nanda R. Shrestha for his insightful guidance during the formative phases of this research. Dr. Darlene Budd deserves special thanks for her initial comments on sociopolitical and demographic aspects that helped to shape this research. We want to thank to Prof. David Rice of the Center for Teaching and Learning, University of Central Missouri for his encouragement and support in software and data acquisition.

\section{References}

[1] D. Alexander and K. Smith, "Environmental Hazards: Assessing Risk and Reducing Disaster," Progress in Physical Geography, Vol. 17, 1993, pp. 503-504.

[2] T. Rashed and J. Weeks, "Assessing Vulnerability to Earthquake Hazards through Spatial Multicriteria Analysis of Urban Areas," International Journal of Geographical Information Science, Taylor and Francis Ltd., London/Bristol, 2002. http://www.tandf.co.uk/journals

[3] F. Wu and C. J. Webster, "Simulating Artificial Cities in a GIS Environment: Urban Growth under Alternative Regulation Regimes," International Journal of Geographical Information Science, Vol. 14, No. 7, 2000, pp.
625-648.

[4] W. Zuo and Q. Chen, "Real-Time or Faster-Than-Real-Time Simulation of Airflow in Buildings," Indoor Air, Vol. 19, 2009, pp. 33-44. www.blackwell-publishing.com /ina

[5] A. P. Adhikari, "Urban Planning," My Republica, 2009. http://www.myrepublica.com/portal/index.php?action=ne ws_details\&news_id $=12092$

[6] D. Alexander, "Confronting Catastrophe: New Perspectives on Natural Disasters," Natural Disasters, Chapman \& Hall, Inc, New York, 1993, pp. 12-14.

[7] L. G. Kaplan, "Emergency and Disaster Planning Manual," McGraw-Hill, New York, 1996.

[8] B. Richardson, "Socio-Technical Disaster: Profile and Prevalence," Disaster Prevention and Management, Vol. 3, No. 4, 1994, pp. 41-69.

[9] I. M. Shaluf, "Disaster Types," Disaster Prevention and Management, Vol. 16, No. 5, 2007, pp. 704-717.

[10] I. Benenson and P. M. Torrens, "Geosimulation: Automata-Based Modeling of Urban Phenomena," John Wiley and Sons, London, 2004.

[11] P. M. Torrens, "Simulating Sprawl," Annals of the Association of American Geographers, Vol. 96, No. 2, 2006, pp. 248-275.

[12] P. Blaikie, T. Cannon, I. Davis and B. Wiser, "At Risk: Natural Hazards, People's Vulnerability, and Disasters," 2nd Edition, Routledge, London, 1994.

[13] T. Rashed and J. Weeks, "Assessing Vulnerability to Earthquake Hazards through Spatial Multicriteria Analysis of Urban Areas," International Journal of Geographical Information Science, Vol. 17, No. 6, 2003, pp. 547-576.

[14] N. Pissinou, I. Radev and K. Kia, "Spatio-Temporal Modeling in Video and Multimedia," Geographic Information Systems, Vol. 5, No. 4, 2001, pp. 375-409.

[15] D. Alexander, "Confronting Catastrophe: New Perspectives on Natural Disasters," Oxford University Press, New York, 2000.

[16] I. Burton, R. W. Kates and G. F. Whit, "The Environment as Hazard," Oxford University Press, New York, 1978.

[17] K. Heweitt, "Regions of Risk: A Geographical Introduction to Disasters," Harlow, Longman, 1997.

[18] A. Koeninger and S. Bartel, "3D-GIS for Urban Purposes," Geographic Informatica, Vol. 2, No. 1, 1998, pp. 79-103.

[19] D. S. Mileti, "Disasters by Design: A Reassessment of Natural Hazards in the United States," Joseph Henry Press, Washington, D.C., 1999.

[20] S. Menoni, "Chains of Damages and Failures in a Metropolitan Environment: Some Observations on the Kobe Earthquake in 1995," Journal of Hazardous Materials, Vol. 83, 2001, pp. 101-119.

[21] G. F. White and J. E. Hass, "Assessment of Research on Natural Hazards," S. L. Cutter, Ed., N. J. Prentice Hall, Englewood Cliffs, 1975, pp. 69-74.

[22] C. J. Webster, "GIS and Scientific Inputs to Urban Planning: Prediction and Prescription," Environment and 
Planning B, Vol. 21, No. 2, 1994, pp. 145-157.

[23] S. L. Cutter, "GI Science, Disasters, and Emergency Management," Transactions in GIS, Vol. 7, No. 4, 2003, pp. 439-445.

[24] B. B. Madhavan, S. Kubo, N. Kurisaki and T. V. N. Sivakumar, "Appraising the Anatomy and Spatial Growth of the Bangkok Metropolitan Area Using a VegetationImpervious-Soil Model through Remote Sensing," International Journal of Remote Sensing, Vol. 22, No. 5, 2001, pp. 789-806.

[25] S. Bhaskaran, B. Datt, T. Forster, T. Neal and M. Brown, "Integrating Imaging Spectroscopy (445-2543 Nm) and Geographic Information Systems for Post-Disaster Management: A Case of Hailstorm Damage in Sydney," International Journal of Remote Sensing, Vol. 25, No. 13, 2004, pp. 2625-2639.

[26] A. Bottari, P. Bottari, C. Carveni, C. Sacco and A. Teramo, "Evidence of Seismic Deformation of the Paved Floor of the Decumanus at Tindari (NE, Sicily)," Geophysical Journal International, Vol. 174, No. 1, 2008, pp. 213-222.

[27] M. Zamoranoa, E. Molerob, A. Hurtadoa, A. Grindlayb and A. Ramos, "Evaluation of a Municipal Landfill Site in Southern Spain with GIS-Aided Methodology," Journal of Hazardous Materials, Vol. 160, No. 2-3, 2008, pp. 473-481.

[28] M. Komazawa, H. Morikawa, K. Nakamura, J. Akamatsu, K. Nishimura, S. Sawada, A. Erken and A. Onalp, "Bedrock Structure in Adapazari, Turkey-A Possible Cause of Severe Damage by the 1999 Kociaeli Earthquake," Soil Dynamics and Earthquake Engineering, Vol. 22, No. 9, 2002, pp. 829-836.

[29] D. V. Pullar and M. J. Egenhofer, "Toward Formal Definition of Topological Relations among Spatial Objects," Proceedings of the Third International Symposium on SDH, Singapore, 1998, pp. 225-241.

[30] J. Lee, "A Three-Dimensional Navigable Data Model to Support Emergency Response in Microspatial Built-Environments," Annals of the Association of American Geographers, Vol. 97, No. 3, 2007, pp. 512-529.

[31] S. Zlatanova, "3D GIS for Urban Development," Ph.D. Dissertation, International Institute for Geo-Information Science and Earth Observation (ITC), Enschede, 2000.

[32] R. Billen and S. Zlatanova, "3D Spatial Relationships Model: A Useful Concept for 3D Cadastre?" Computers, Environment and Urban Systems, Vol. 27, No. 4, 2003, pp. 411-425.

[33] Economic and Social Research Institute (ESRI), "What's Coming in ArcGIS 10 Desktop?" 2010. http://www.esri. com/software/arcgis/whats-new/index.html

[34] M. P. Kwan, "Feminist Visualization: Re-Envisioning GIS as Method in Feminist Geographic Research," Annals of the Association of American Geographers, Vol. 92, No. 4, 2002, pp. 645-661.

[35] R. V. Whiteman and H. J. Lagorio, "The FEMA-NIBS Methodology for Earthquake Loss Estimation," FEMA Toshihisa Toyoda, 1998, 2001. http:// www.nibs.org/ ha- zus4a.html

[36] L. Matejicek, P. Engst and Z. Jaňour, "A GIS-Based Approach to Spatio-Temporal Analysis of Environmental Pollution in Urban Areas: A Case Study of Prague's Environment Extended by LIDAR Data," Ecological Modelling, Vol. 199, No. 3, 2006, pp. 261-277.

[37] H. Demirel, "A Generic Data Model Proposal for MultiDimensional Road Object," International Archives of Photogrammetry, Remote Sensing and Spatial Information Sciences, Vol. 35, 2004, pp. 1312-1317.

[38] ERDAS, "The Earth Business Company," 2010. http:// www.erdas.com/ default.aspx

[39] Q. Zhu and Y. Li, "Hierarchical Lane-Oriented 3D RoadNetwork Model," International Journal of Geographical Information Science, Vol. 22, No. 5, May 2008, pp. 479 505.

[40] K. Bhattarai and D. Conway, "Urban Sprawl in the Kathmandu Valley," In: S. Devkota, Ed., Nepal in the $21^{\text {st }}$ Century, 4th Edition, Nova Science Publishers Inc, New York, 2010.

[41] P. P. Karan, "The Physical Development Plan for the Kathmandu Valley," Journal Asiatique, 1969, p. 195.

[42] B. N. Haack and A. Rafter, "Urban Growth Analysis and Modeling in the Kathmandu Valley," Habitat International, Vol. 30, No. 4, 2006, pp. 1056-1065.

[43] H. Koirala, "RS and GIS in Assessing Urban Environment: A Case Study of the Kathmandu Metropolitan City," 2000. http://www.pages.hotbot.com/edu.geoinform atics/f118.html

[44] KVTDC, "Kathmandu Valley Town Development Committee," Long-Term Development Concept of Kathmandu Valley Urban Development Committee, Kathmandu, 2002.

[45] LRMP, Land Resource Mapping Project, HMG published maps for Nepal at 1: 50,000 Scale, 1986.

[46] R. B. Thapa, Y. Murayama and S. Ale, "City Profile: Kathmandu," Cities, Vol. 25, No.1, 2008, pp. 45-57.

[47] A. M. Dixit, "National Society for Earthquake Technology-Nepal (NSET)," BBC Nepali interview, 16 January 2010.

[48] "Haiti Earthquake: News Updates," CNN News, 2010. http://www.cnn.com/2010/WORLD/americas/01/16/haiti. updates.sat/index.html

[49] P. Andreas, "Images of Century, the Changing Townscapes of the Kathmandu Valley," GTZ/UNDP, 1995.

[50] B. K. Shrestha and S. Shrestha, "Preparedness is the Key," My Republica, 2010. http://myrepublica.com /portal/ index.php?action=news_details\&news_id $=14096$

[51] BBC, 2010. http://news.bbc.co.uk/2/hi/europe/8554857.stm

[52] P. Pradhan and R. Perera, "Urban Growth and its Impact on the Livelihoods of Kathmandu Valley," UMP-Asia Occasional Paper, No. 63, 2005.

[53] Nature March, Vol. 386, Nature, 2006, September, Vol. 4, 1997.

[54] J. Joshi, "Planning Approaches in Nepal," J. Lajmina, Ed., 2008, p. 162. 
[55] J. Joshi, "Housing and Urban Development in Nepal: An Analysis and Design of Participatory Development Process," Revised Edition, Naveen Press, Kathmandu, 1999.

[56] A. P. Adhikari, "Urban and Environmental Planning in Nepal: Analysis, Policies and Proposals," IUCN-The World Conservation Union, 1998, p. 132.

[57] MDM, Mechidekhi Mahakalisamma, Madhyamanchal Bikaschhetra, A publication of Nepal Government, 1971.

[58] J. Hardoy and D. Satterthwaite, "Shelter Need and Response: Housing, Land and Settlement Policy in Seventh Third World Countries," John Wiley, Chichester, 1981.

[59] CBS, Centre Bureau of Statistics, Government of Nepal, Kathmandu, 2008.

[60] M. Degg, "Natural Disasters: Recent Trends and Future Prospects," Geography, Vol. 77, No. 3, 1992, pp. 198- 209.

[61] Centre Bureau of Statistics (CBS), His Majesty's Government of Nepal, Kathmandu, 2006.

[62] DOR, "Department of Roads: List of Important Roads and Status," Road Statistics, Government of Nepal, 2004.

[63] K. Poudel, "Power Crisis," Spotlight, April 2007.

[64] E. Mood, et al., "Housing Codes Standards: Three Critical Studies," The National Commission of Urban Problems, Washington, D.C., 1969.

[65] C. P. Lo, "Estimating Population and Census Data," In: M. K. Ridd and J. D. Hipple Eds., Remote Sensing of Human Settlements: Manual of Remote Sensing, 3rd Edition, ASPRS, The Image \& Geospatial Information Society, 2006, pp. 337-399.

[66] The Kathmandu Post, 2003.

[67] U. Sengupta and S. Sharma, "The Challenge of Squatter Settlements in Kathmandu: Addressing a Policy Vacuum," International Development Planning Review, Vol. 28, No. 1, 2006, pp. 105-126.

[68] "Urban Health in Daily Practice: Livelihood, Vulnerability and Resilience in Dar Es Salaam," Anthropology \& Medicine, Vol. 10, No. 3, 2003, pp. 361-371.

[69] S. A. Moore, "The Excess of Modernity: Garbage Politics in Oaxaca, Mexico," The Professional Geographer, Vol. 61, No. 4, 2009, pp. 426-437.

[70] T. Ojima, "Japanese Geo-Space Infrastructural System," In: G. S. Golany and O. Toshio, Eds., Geo-Space Urban Design, John Wiley and Sons, Inc., New York, 1996, pp. 257-310.

[71] U. Beck, "Risk Society Revisited: Theory, Politics and Research Programs," In: B. Adam, U. Beck and J. Van Loon, Eds., The Risk Society and Beyond: Critical Issues for Social Theory, London, 2000, pp. 211-229.

[72] S. C. Gomez, "The Challenge of Post Modernity to Latin American Philosophy," In: E. Mediaeta and P. LangeChurion, Eds., Latin America and Postmodernity: A conTemporary Reader, Humanity Books, New York, 2001, pp. 123-154.

[73] H. Caminos and G. Reinhard, Urbanization Primer, MIT Press, Cambridge, 1978.
[74] UN Department of Economic and Soail Affairs, "Climate and Housing Design of Low Cost Housing and Community Facilities," New York, 1968.

[75] Kantipuronline, "Over 181,000 New Vehicles Registered in Last 5 Years Staggering Growth in Capital'S Vehicles," 30 July 2009. http://www.kantipuronline.com

[76] T. H. Kolbe, G. Groger and L. Plumer, "CityGMLInteroperable Access to 3D City Models," In: P. van Oosterom, S. Zlatanova and E. M. Fendel, Eds., Geo-Information for Disaster Management, Springer, New York, 2005, pp. 883-900.

[77] L. G. Chalmet, R. L. Francis and P. B. Sunders, "Network Models for Building Evacuation," Management Science, Vol. 28, No. 1, 1982, pp. 86-105.

[78] M. J. Egenhofer and A. Herring, "A Mathematical Framework for the Definition of Topological Relationships," In: K. Brassel and H. Kishimoto, Eds., Proceedings of the fourth International Symposium on SDH, Zurich, 1990, pp. 803-813.

[79] E. L. Glaeser, J. Gyourko and R. E. Saks, "Research Working Papers Series Urban Growth and Housing Supply," Research Working Papers Series, 2005. http://www. hks.havard.edu/taubmancenter/pdfs/working_papers/Glae ser_05_Growth

[80] A. Hengaju, A Firefighter with Basantapur Fire Brigade (BFB) was Interviewed in Rai, 2010.

[81] Pacione, M., "Urban Geography: A Global Perspective," 2nd Edition, Routeledge, London, 2005, pp. 309-310.

[82] J. R. Short, "The Urban Order: An Introduction to Urban Geography," In: J. Kaplan, J. Wheeler and S. Holloway, Eds., Urban Geography, John Wiley \& Sons, Inc., New York, 2009, p. 512.

[83] M. A. P. Taylor, "Critical Transport Infrastructure in Urban Areas: Impacts of Traffic Incidents Assessed Using Accessibility-Based Network Vulnerability Analysis," Growth and Change, Vol. 39, No. 4, 1995, pp. 593-616.

[84] A. D. May, M. Roberts and P. Mason, "The Development of Transport Strategies for Edinburgh, Civil, Environmental and Geomatic Engineering Transportation, Vol. 95, 1992, pp. 51-59.

[85] P. W. Wilson, "Welfare Effects of Congestion Pricing in Singapore," Transportation, Vol. 15, No. 3, 1988, pp. 191210.

[86] Greater London Council, "A Study of Supplementary Licensing," Gt. London Council, London, 1974.

[87] R. A. Vincent and R. E. Layfield, "Nottingham Zones and Collar Scheme - The Overall Assessment," Lab. Rep. 805, Transport and Road Research Laboratory, Crowthorne, 1978.

[88] A. Kalaizedes, Pers. Com. on Grece Transportation System, Associate Professor of Political Science at the University of Central Missouri, 2010. 